\title{
Short Synthesis of Octosyl Nucleosides
}

Spencer Knapp, ${ }^{*}{ }^{\dagger}$ Vinay V. Thakur, ${ }^{\dagger}$ Machender R. Madduru, ${ }^{\dagger}$ Krishnan Malolanarasimhan, ${ }^{\dagger}$ Gregori J. Morriello, ${ }^{\ddagger}$ and George A. Doss ${ }^{\ddagger}$

${ }^{\dagger}$ Department of Chemistry \& Chemical Biology, Rutgers - The State University of New Jersey, 610 Taylor Road, Piscataway, NJ 08854, and ${ }^{\ddagger}$ Merck \& Co., P. O. Box 2000, Rahway, New Jersey 07065

\section{Supporting Information}

\section{Page}

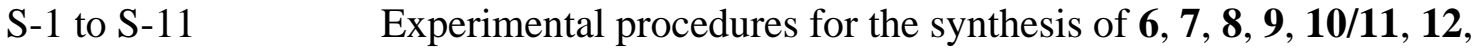
$13,14,15,16,17,18,19,2$, and 1 .

S-12 to S-24 Copies of ${ }^{1} \mathrm{H}$ and ${ }^{13} \mathrm{C}$ NMR spectra of $\mathbf{6 , 7}, \mathbf{8}, \mathbf{9}, \mathbf{1 2}, \mathbf{1 3}, \mathbf{1 4}, \mathbf{1 5}, \mathbf{1 7}$, 18, 19, 2, and 1 .
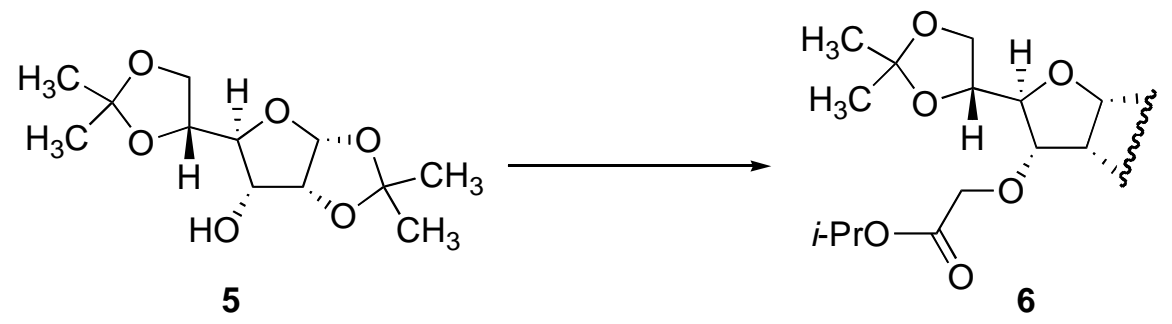

Compound 6. A solution of $0.260 \mathrm{~g}$ (1 mmol) of commercial 1,2,5,6-di-Oisopropylidene- $\alpha$-D-allofuranose (5) in $3.0 \mathrm{~mL}$ of dry THF was treated with $0.391 \mathrm{~mL}$ (1.5 mmol) of 2-tert-butylimino-2-diethylamino-1,3-dimethyl-perhydro-1,3,2-diazaphosphorine (BEMP) at $0{ }^{\circ} \mathrm{C}$ with stirring. After $10 \mathrm{~min}, 0.168 \mathrm{~mL}(1.3 \mathrm{mmol})$ of isopropyl bromoacetate was added at the same temperature and reaction was allowed to come to room temperature. After 48 
$\mathrm{h}$ the reaction was quenched with saturated ammonium chloride solution and then concentrated. The crude product was extracted with ethyl acetate $(3 \times 10 \mathrm{~mL})$, and the combined extract was dried over anhydrous sodium sulfate, concentrated to a pale oil, and then chromatographed with 1:4 ethyl acetate / petroleum ether as the eluant to give $0.340 \mathrm{~g}$ (95\%) of 6 as a gum. ${ }^{1} \mathrm{H}$ NMR $\left(\mathrm{CDCl}_{3}, 300 \mathrm{MHz}\right) \delta 1.20(\mathrm{~d}, J=6.3 \mathrm{~Hz}, 6 \mathrm{H}), 1.30$ (s, $\left.6 \mathrm{H}\right), 1.40$ (s, $\left.3 \mathrm{H}\right), 1.52$ (s, $\left.3 \mathrm{H}\right), 3.84$ (dd, $J=4.6,8.6 \mathrm{~Hz}, 1 \mathrm{H}$ ), 3.96 (dd, $J=6.6,15.0 \mathrm{~Hz}, 1 \mathrm{H}$ ), 3.99 (obscured dd, $1 \mathrm{H}$ ), 4.02 (dd, $J=$ 6.6, $15.0 \mathrm{~Hz}, 1 \mathrm{H}$ ), 4.12 (d, $J=16.5 \mathrm{~Hz}, 1 \mathrm{H}$ ), 4.24 (d, $J=16.8 \mathrm{~Hz}, 1 \mathrm{H}$ ), 4.25 (obscured dt, $1 \mathrm{H}$ ), $4.71(\mathrm{t}, J=4.5 \mathrm{~Hz}, 1 \mathrm{H}), 5.02$ (sept, $J=6.2 \mathrm{~Hz}, 1 \mathrm{H}), 5.68$ (d, $J=3.6 \mathrm{~Hz}, 1 \mathrm{H})$; ${ }^{13} \mathrm{C}$ NMR $\left(\mathrm{CDCl}_{3}, 75 \mathrm{MHz}\right) \delta 22.1,22.1,25.4,26.6,26.9,27.1,65.9,68.4,68.9,75.5,78.3,79.0,80.5$, 103.7, 109.8, 113.2, 169.9; FAB-MS m/z $383\left(\mathrm{MNa}^{+}\right)$.
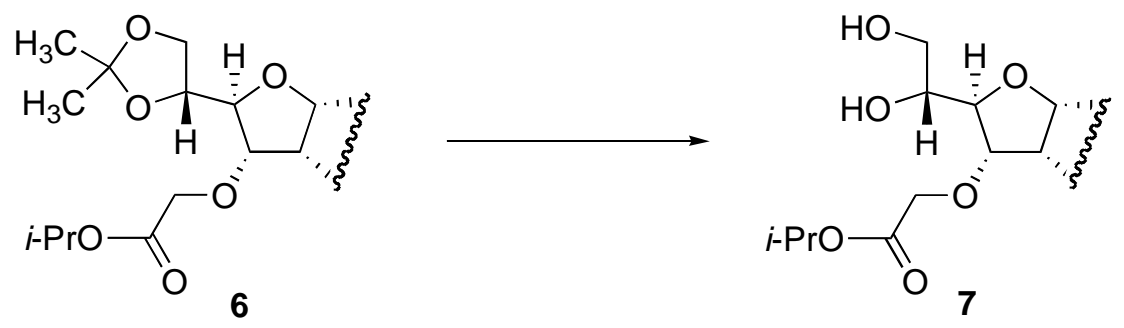

Compound 7. A solution of $0.510 \mathrm{~g}$ (1.42 mmol) of 6 in $6 \mathrm{~mL}$ of $75 \%$ aq acetic acid was stirred at room temperature for $6 \mathrm{~h}$, by which time TLC analysis indicated no more than a trace of starting material remained. The solvent was removed by vacuum codistillation with toluene (3 $\mathrm{x} 4 \mathrm{~mL}$ ), and the residue was chromatographed with 2:3 ethyl acetate / petroleum ether as the eluant to afford $0.400 \mathrm{~g}(88 \%)$ of diol 7 as a gum. ${ }^{1} \mathrm{H}$ NMR $\left(\mathrm{CDCl}_{3}, 300 \mathrm{MHz}\right) \delta 1.25$ and 1.28 (two d, $J=6.3 \mathrm{~Hz}, 3 \mathrm{H}$ each), 1.34 (s, $3 \mathrm{H}$ ), 1.56 (s, $3 \mathrm{H}$ ), 3.05 (br s, $2 \mathrm{H}$ ), 3.74 (d, $J=4.5 \mathrm{~Hz}, 2$ H), 3.87-3.94 (m, 2 H), 4.01 (dd, $J=4.8,8.4 \mathrm{~Hz}, 1 \mathrm{H}), 4.06$ (d, $J=16.8 \mathrm{~Hz}, 1 \mathrm{H}), 4.32$ (d, $J=$ $16.8 \mathrm{~Hz}, 1 \mathrm{H}$ ), 4.65 (t, $J=4.0 \mathrm{~Hz}, 1 \mathrm{H}$ ), 5.09 (sept, $J=6.1 \mathrm{~Hz}, 1 \mathrm{H}$ ), 5.74 (d, $J=3.9 \mathrm{~Hz}, 1 \mathrm{H}$ ); ${ }^{13} \mathrm{C} \mathrm{NMR}\left(\mathrm{CDCl}_{3}, 75 \mathrm{MHz}\right) \delta 22.0,22.1,26.9,27.0,63.4,67.4,69.7,72.0,77.5,78.5,80.0$, 104.2, 113.4, 170.4; FAB-MS m/z $343\left(\mathrm{MNa}^{+}\right)$. 

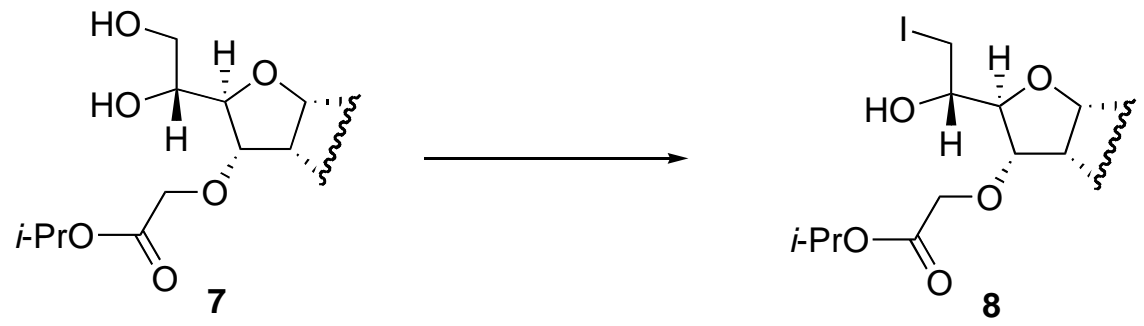

Compound 8. A solution of $0.320 \mathrm{~g}(1 \mathrm{mmol})$ of 7 and $0.392 \mathrm{~g}(1.5 \mathrm{mmol})$ of triphenylphosphine in $3 \mathrm{~mL}$ of acetonitrile was cooled to $-10{ }^{\circ} \mathrm{C}$ in an ice salt bath. A solution of $0.307 \mathrm{~g}$ (1.21 mmol) of iodine in $1.0 \mathrm{~mL}$ of dry DMF was added dropwise with stirring at the same temperature. The reaction mixture was allowed to warm to room temperature and to stir for $46 \mathrm{~h}$. The reaction was quenched with saturated aq sodium bicarbonate and extracted with ethyl acetate $(3 \times 15 \mathrm{~mL})$. The combined organic extract was washed with $5 \mathrm{~mL}$ of brine, dried over anhydrous sodium sulfate, concentrated to a residue, and then chromatographed with 1:3 ethyl acetate / petroleum ether as the eluant to give $0.322 \mathrm{~g}$ (75\%) of iodo alcohol 8 as a viscous liquid. ${ }^{1} \mathrm{H}$ NMR $\left(\mathrm{CDCl}_{3}, 300 \mathrm{MHz}\right) \delta 1.27$ (d, $\left.J=6.3 \mathrm{~Hz}, 6 \mathrm{H}\right), 1.36$ (s, $\left.3 \mathrm{H}\right), 1.59$ (s, $3 \mathrm{H}$ ), 2.78 (br s, OH), 3.38 (dd, $J=7.2,10.5$ Hz, 1 H); 3.50 (dd, $J=3.3,10.5$ Hz, 1 H), 3.69 (dt, $J=3.3,7.2$ Hz, 1 H), 3.86 (dd, $J=4.2,8.7$ Hz, 1 H), 4.02 (dd, $J=6.6,8.4$ Hz, 1 H) 4.08 (d, $J=16.8 \mathrm{~Hz}$, 1H), 4.34 (d, $J=16.8 \mathrm{~Hz}, 1 \mathrm{H}$ ), 4.67 (t, $J=3.9 \mathrm{~Hz}, 1 \mathrm{H}$ ), 5.12 (sept, $J=6.3 \mathrm{~Hz}, 1 \mathrm{H}$ ), 5.71 (d, $J=$ $3.6 \mathrm{~Hz}, 1 \mathrm{H}) ;{ }^{13} \mathrm{C} \mathrm{NMR}\left(\mathrm{CDCl}_{3}, 75 \mathrm{MHz}\right) \delta 9.9,22.0,22.1,27.0,27.1,67.3,69.9,72.5,77.4$, 79.2, 81.2, 104.0, 113.7, 170.8; FAB-MS m/z $453\left(\mathrm{MNa}^{+}\right)$.
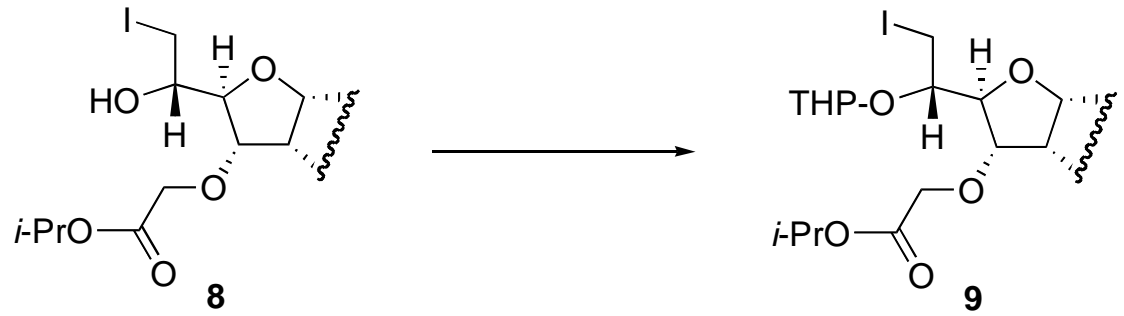

Compound 9. A solution of $0.215 \mathrm{~g}(0.5 \mathrm{mmol})$ of iodo alcohol 8 in $3.0 \mathrm{~mL}$ of dichloromethane was treated with $0.46 \mathrm{~mL}$ ( $5 \mathrm{mmol}$ ) of 3,4-dihydro- $2 \mathrm{H}$-pyran and $0.013 \mathrm{~g} \mathrm{(0.05}$ mmol) of pyridinium p-toluenesulfonate, and the resulting solution was stirred at room temperature for $5 \mathrm{~h}$. The reaction was quenched with saturated aq sodium bicarbonate, and the aqueous phase was extracted with dichloromethane $(2 \times 5 \mathrm{~mL})$. The combined organic extract was dried over anhydrous sodium sulfate, concentrated, and then chromatographed with 1:4 ethyl 
acetate / petroleum ether as the eluant to give $0.213 \mathrm{~g}$ (85\%) of $\mathbf{9}$ as an oily mixture of two diastereomers. ${ }^{1} \mathrm{H}$ NMR $\left(\mathrm{CDCl}_{3}, 400 \mathrm{MHz}\right) \delta 1.24-1.28$ (m, $\left.6 \mathrm{H}\right), 1.36$ (s, $\left.1.5 \mathrm{H}\right), 1.37$ (s, $\left.1.5 \mathrm{H}\right)$, 1.46-1.58 (m, 4 H), 1.59 (s, 3 H), 1.62-1.82 (m, 2 H), 3.35 (dd, $J=6.0,10.4$ Hz, 0.5 H), 3.403.54 (m, 1.5 H), 3.87-3.94 (m, 1 H), 3.95-4.11 (m, 2 H), 4.11-4.34 (m, 2 H), 4.34 (dd, $J=2.4$, $8.2 \mathrm{~Hz}, 0.5 \mathrm{H}$ ), 4.49 (dd, $J=2.4,8.2 \mathrm{~Hz}, 0.5 \mathrm{H}), 4.67$ (t, $J=4.0 \mathrm{~Hz}, 0.5 \mathrm{H}), 4.71$ (t, $J=4.0 \mathrm{~Hz}$, 0.5 H), 4.75-4.81 (m, 1 H), 5.09 (sept, $J=6.3$ Hz, 1 H), 5.69 (d, $J=3.6$ Hz, 0.5 H), 5.73 (d, $J=$ $3.6 \mathrm{~Hz}, 0.5 \mathrm{H})$; ${ }^{13} \mathrm{C} \mathrm{NMR}\left(\mathrm{CDCl}_{3}, 100 \mathrm{MHz}\right) \delta$ 4.0, 4.3, 19.7, 19.9, 21.9, 25.3, 25.4, 26.8, 27.0, 27.0, 29.7, 30.7, 30.9, 63.1, 63.1, 67.6, 67.8, 68.7, 68.8, 75.1, 76.7, 78.0, 78.9, 79.4, 79.7, 98.0, 100.9, 103.9, 103.9, 113.4, 113.5, 169.5, 169.9; FAB-MS m/z $537\left(\mathrm{MNa}^{+}\right), 1051\left(\mathrm{M}_{2} \mathrm{Na}^{+}\right)$.
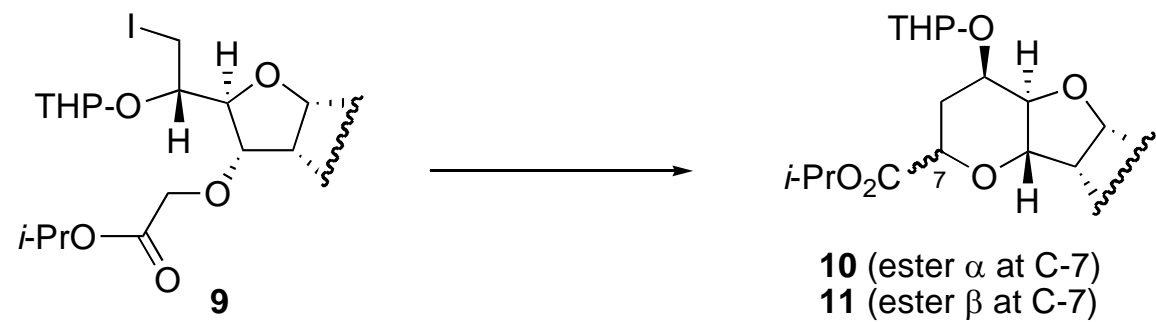

Compounds 10 and 11. A solution of $n$-BuLi (1.6 M in hexanes, $0.53 \mathrm{~mL}, 0.84 \mathrm{mmol}$ ) was added to a solution of $0.12 \mathrm{~mL}(0.84 \mathrm{mmol})$ of diisopropylamine in $20 \mathrm{~mL}$ of dry THF at $78{ }^{\circ} \mathrm{C}$. After $10 \mathrm{~min}$ a solution of $0.110 \mathrm{~g}(0.21 \mathrm{mmol})$ of 9 in $60 \mathrm{~mL}$ of dry THF was added, and the reaction mixture was stirred at $-78{ }^{\circ} \mathrm{C}$ for $2.5 \mathrm{~h}$. The reaction was quenched with saturated aq ammonium chloride, concentrated, and then extracted with EtOAc (3 x $15 \mathrm{~mL}$ ). The combined organic extract was dried over anhydrous sodium sulfate, concentrated, and then chromatographed with 1:4 ethyl acetate / petroleum ether as the eluant to afford $28 \mathrm{mg}$ (25\%) of 9 and 54 mg (65\% yield, 87\% based on recovered 9) of cyclized product 10/11 as a mixture of four diastereomers. The latter mixture was converted to the 5-O-acetates, which facilitated full spectroscopic characterization (see below). FAB-MS m/z $409\left(\mathrm{MNa}^{+}\right), 795\left(\mathrm{M}_{2} \mathrm{Na}^{+}\right)$. 


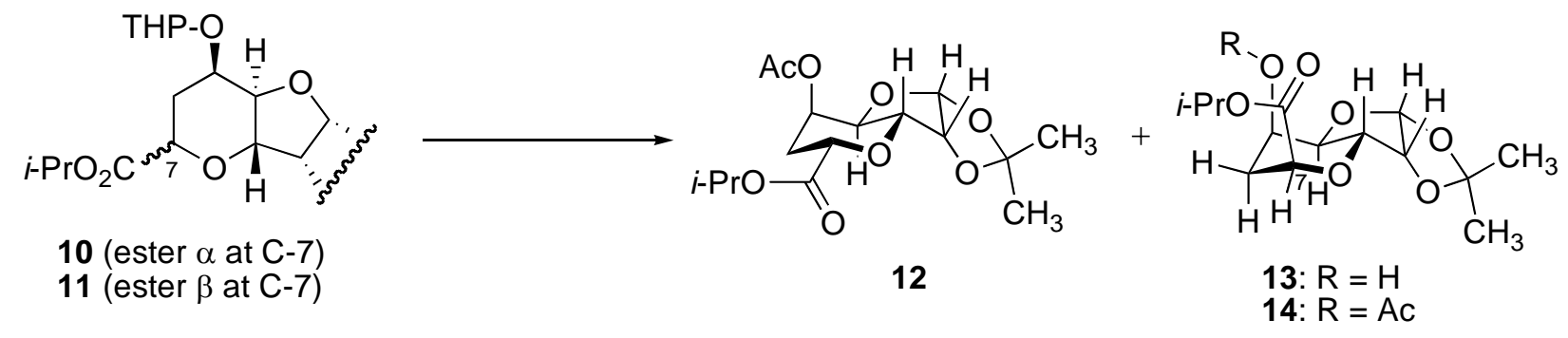

Acetates 12 and 14. A solution of the mixture 10/11 (25 mg, $0.065 \mathrm{mmol})$ in $2 \mathrm{~mL}$ of 4:2:1 acetic acid / THF / water was heated at $40-ß 45{ }^{\circ} \mathrm{C}$ for $5 \mathrm{~h}$. The solution was concentrated, and the remaining trace of acetic acid was removed by azeotropic codistillation with toluene $(2 \mathrm{x}$ $2 \mathrm{~mL}$ ), and then vacuum drying to constant weight. The resulting crude alcohol was dissolved in $1.0 \mathrm{~mL}$ of dichloromethane, and then treated with $0.10 \mathrm{~mL}(1.0 \mathrm{mmol})$ of acetic anhydride and $0.10 \mathrm{~mL}(1.3 \mathrm{mmol})$ of pyridine. The reaction was stirred overnight at room temperature, concentrated, and then chromatographed with 2:3 ethyl acetate / petroleum ether as the eluant to provide $12 \mathrm{mg}$ (54\%, 47\% overall from 9) of acetate 12 and $6 \mathrm{mg}$ (30\%, 27\% overall from 9) of carbinol 13.

Data for 12: ${ }^{1} \mathrm{H}$ NMR $\left(\mathrm{CDCl}_{3}, 400 \mathrm{MHz}\right) \delta 1.22$ and 1.26 (two d, $J=6.3 \mathrm{~Hz}, 3 \mathrm{H}$ each), 1.34 (s, 3 H), 1.58 (s, 3 H), 1.95 (ddd, $J=2.4,12.0,14.8 \mathrm{~Hz}, 1 \mathrm{H}), 2.12$ (s, $3 \mathrm{H}), 2.25$ (br td, $J=$ 3.2, $14.8 \mathrm{~Hz}, 1 \mathrm{H}$ ), 3.72 (dd, $J=4.2,9.9 \mathrm{~Hz}, 1 \mathrm{H}$ ), 3.95 (dd, $J=2.2$, $9.9 \mathrm{~Hz}, 1 \mathrm{H}$ ), 4.34 (dd, $J=$ 2.7, $12.3 \mathrm{~Hz}, 1 \mathrm{H}$ ), 4.69 (t, $J=3.6 \mathrm{~Hz}, 1 \mathrm{H}$ ), 5.08 (sept, $J=6.3 \mathrm{~Hz}, 1 \mathrm{H}$ ), 5.58 (br q, $J=2.8 \mathrm{~Hz}, 1$ H), $5.76(\mathrm{~d}, J=3.3 \mathrm{~Hz}, 1 \mathrm{H}) ;{ }^{13} \mathrm{C} \mathrm{NMR}\left(\mathrm{CDCl}_{3}, 100 \mathrm{MHz}\right) \delta$ 21.1, 21.7, 26.0, 26.4, 29.7, 30.0, 66.2, 69.3, 72.8, 73.5, 75.2, 76.3, 104.7, 114.0, 168.7, 169.9; FAB-MS m/z $367\left(\mathrm{MNa}^{+}\right)$. Anal. Calcd for $\mathrm{C}_{16} \mathrm{H}_{24} \mathrm{O}_{8}$ : C, 55.81; H, 7.02. Found: C, 55.86; H, 7.10.

Data for 13: ${ }^{1} \mathrm{H}$ NMR $\left(\mathrm{CDCl}_{3}, 400 \mathrm{MHz}\right) \delta 1.28$ (app t, $\left.J=6.0 \mathrm{~Hz}, 6 \mathrm{H}\right), 1.37$ (s, $\left.3 \mathrm{H}\right)$, 1.60 (s, 3 H), 2.05-2.11 (m, 2 H), 2.53 (dd, $J=3.6,15.2$ Hz, 1 H), 3.87 (dd, $J=2.4,10.0 \mathrm{~Hz}, 1$ H), 4.23 (dd, $J=4.0,10.0 \mathrm{~Hz}, 1 \mathrm{H}$ ), 4.42 (d, $J=7.2 \mathrm{~Hz}, 1 \mathrm{H}), 4.46$ (d, $J=2.0 \mathrm{~Hz}, 1 \mathrm{H}), 4.78$ (t, $J$ $=4.0 \mathrm{~Hz}, 1 \mathrm{H}) 5.11$ (sept, $J=6.0 \mathrm{~Hz}, 1 \mathrm{H}), 5.78(\mathrm{~d}, J=3.6 \mathrm{~Hz}, 1 \mathrm{H}) ;{ }^{13} \mathrm{C} \mathrm{NMR}\left(\mathrm{CDCl}_{3}, 100\right.$ MHz) $\delta 21.7,21.7,26.0,26.3,32.1,64.9,69.0,69.6,71.4,74.9,76.9,104.5,113.8,171.2$; FABMS m/z $325\left(\mathrm{MNa}^{+}\right), 627\left(\mathrm{M}_{2} \mathrm{Na}^{+}\right)$.

For further characterization, 13 (6 mg) was converted to its acetate 14 (5.5 mg, 80\%) under more forcing conditions (acetic anhydride, pyridine, catalytic DMAP). ${ }^{1} \mathrm{H} \mathrm{NMR}\left(\mathrm{CDCl}_{3}\right.$, 
$400 \mathrm{MHz}$ ) $\delta 1.28$ and 1.29 (two d, $J=6.0 \mathrm{~Hz}, 3 \mathrm{H}$ each), 1.36 (s, $3 \mathrm{H}$ ), 1.59 (s, $3 \mathrm{H}$ ), 2.01 (s, 3 H), 2.14 (ddd, $J=2.6,7.6,15.2 \mathrm{~Hz}, 1 \mathrm{H}$ ), 2.65 (ddd, $J=0.8,3.6,15.2 \mathrm{~Hz}, 1 \mathrm{H}$ ), 3.91 (dd, $J=$ 2.4, $10.0 \mathrm{~Hz}, 1 \mathrm{H}$ ), 4.17 (dd, $J=4.0,10.0 \mathrm{~Hz}, 1 \mathrm{H}$ ), 4.47 (d, $J=6.8 \mathrm{~Hz}, 1 \mathrm{H}$ ), 4.76 (t, $J=3.6 \mathrm{~Hz}$, $1 \mathrm{H}$ ), 5.07 (sept, $J=6.0 \mathrm{~Hz}, 1 \mathrm{H}$ ), 5.49 (br q, $J=2.4 \mathrm{~Hz}, 1 \mathrm{H}$ ), 5.77 (d, $J=3.2 \mathrm{~Hz}, 1 \mathrm{H}) ;{ }^{13} \mathrm{C}$ NMR $\left(\mathrm{CDCl}_{3}, 100 \mathrm{MHz}\right) \delta$ 21.8, 21.8, 26.0, 26.3, 29.7, 30.2, 66.9, 69.2, 70.8, 71.4, 72.9, 76.6, 104.4, 113.7, 169.8, 170.7; FAB-MS m/z $367\left(\mathrm{MNa}^{+}\right)$.

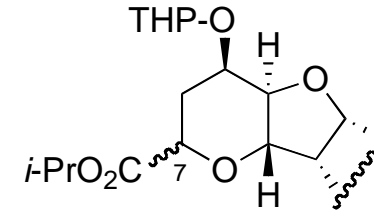

10 (ester $\alpha$ at C-7)

11 (ester $\beta$ at C-7)

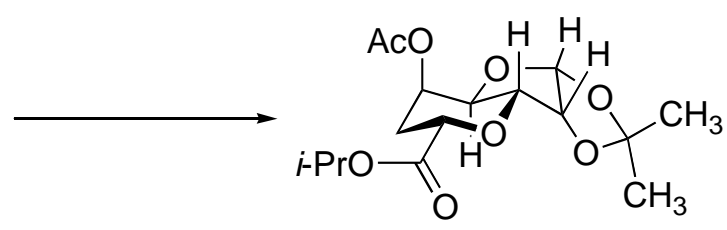

12

Epimerization of 10/11. The $\mathbf{1 0} / \mathbf{1 1}$ mixture $(0.012$ g, $0.031 \mathrm{mmol})$ was treated with a solution of $0.004 \mathrm{~g}(0.034 \mathrm{mmol})$ of potassium tert-butoxide in $0.5 \mathrm{~mL}$ of dry tert-butyl alcohol at room temperature for $3 \mathrm{~h}$, and then concentrated under vacuum. The residue was dissolved in $1.0 \mathrm{~mL}$ of $\mathrm{DMF}$ at $0{ }^{\circ} \mathrm{C}$. Sodium hydride (50\% oil dispersion, $0.003 \mathrm{~g}, 0.06 \mathrm{mmol}$ ) and isopropyl iodide $(0.5 \mathrm{~mL})$ were added, and the reaction mixture was stirred for $20 \mathrm{~h}$. The reaction was quenched with isopropanol and water, and then concentrated. The residue was extracted with ethyl acetate, concentrated, and then passed through a small pad of silica gel with ethyl acetate as the eluant to give $0.010 \mathrm{~g}(83 \%)$ of $\mathbf{1 0}$. This product was hydrolyzed and acetylated at O-5 as before to give $8.0 \mathrm{mg}$ of 12 (89\%, 74\% overall from 10/11, 64\% from 9).

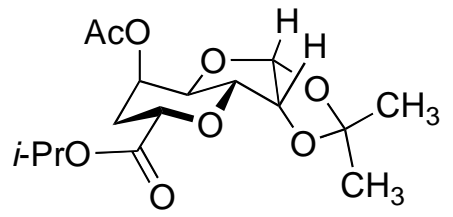

12

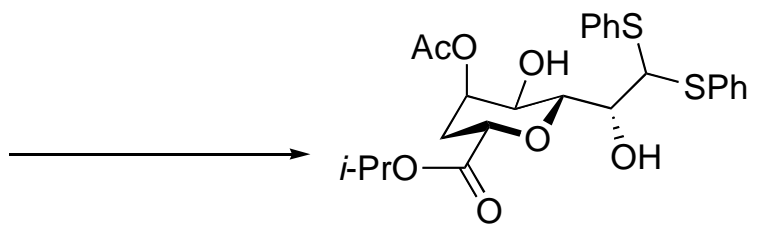

15

Compound 15. Boron trifluoride etherate ( $34 \mu \mathrm{L}, 0.16 \mathrm{mmol})$ was added to a stirred solution of $50 \mathrm{mg}(0.16 \mathrm{mmol})$ of 12 and $0.5 \mathrm{~mL}$ of thiophenol (caution: bad smell) in $1.5 \mathrm{~mL}$ of dichloromethane. After $30 \mathrm{~min}$ the crude reaction mixture was directly chromatographed on silica with 1:4 ether acetate / petroleum ether as the eluant to afford $64 \mathrm{mg}$ (87\%) of 15 as an oil. ${ }^{1} \mathrm{H}$ NMR (CDCl, $400 \mathrm{MHz}$ ) $\delta 1.25$ and 1.23 (two d, $J=6.3 \mathrm{~Hz}, 3 \mathrm{H}$ each), 1.80 (ddd, $J=2.4$, 
12.0, 14.4 Hz, 1 H), 2.12 (partially obscured ddd, 1 H), 2.15 (s, 3 H), 2.67 (s, OH), 3.05 (br s, OH), 3.74 (br d, $J=9.3 \mathrm{~Hz}, 1 \mathrm{H}$ ), 3.83 (dd, $J=2.0,12.4 \mathrm{~Hz}, 1 \mathrm{H}$ ), 3.87 (t, $J=9.3 \mathrm{~Hz}, 1 \mathrm{H}$ ), 4.15 (br d, $J=8.7 \mathrm{~Hz}, 1 \mathrm{H}$ ), 5.05 (sept, $J=6.3 \mathrm{~Hz}, 1 \mathrm{H}$ ), 5.14 (d, $J=1.8 \mathrm{~Hz}, 1 \mathrm{H}$ ), 5.32 (br q, $J=2.8$ $\mathrm{Hz}, 1 \mathrm{H}), 7.24-7.32$ (m, $6 \mathrm{H}), 7.41-7.50$ (m, $4 \mathrm{H}) ;{ }^{13} \mathrm{C} \mathrm{NMR}\left(\mathrm{CDCl}_{3}, 100 \mathrm{MHz}\right) \delta$ 21.2, 21.7, 29.7, 32.6, 61.7, 68.8, 70.7, 71.3, 73.4, 77.1, 127.7, 127.9, 129.0, 129.2, 132.1 (2 C’s), 133.7, 134.4, 169.5, 170.6; FAB-MS m/z $529\left(\mathrm{MNa}^{+}\right)$.
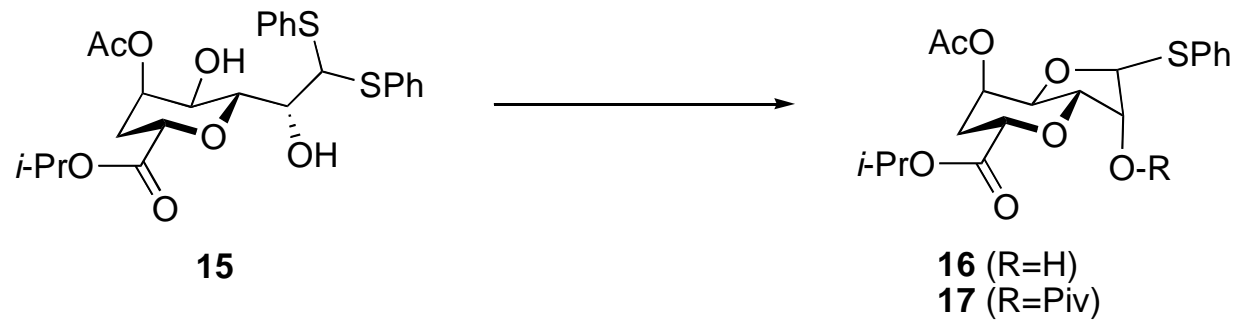

Compound 17. A solution of $50 \mathrm{mg}(0.126 \mathrm{mmol})$ of 15 in $1 \mathrm{~mL}$ of nitromethane was treated with $78.4 \mathrm{mg}(0.328 \mathrm{mmol})$ of silver(I) perchlorate and $45 \mathrm{mg}$ of sodium bicarbonate, and the suspension was stirred for $4 \mathrm{~h}$. The reaction mixture was diluted with $10 \mathrm{~mL}$ of dichloromethane, filtered, concentrated, and chromatographed on silica with 3:7 ethyl acetate / petroleum ether as the eluant to afford $27 \mathrm{mg}$ (69\%) of alcohol 16 as an oil, which was characterized as its pivaloate $\mathbf{1 7}$ prepared as follows. A solution of $5 \mathrm{mg}(0.013 \mathrm{mmol}$ of 16, 6 $\mu \mathrm{L}(0.05 \mathrm{mmol})$ of pivaloyl chloride, $5 \mu \mathrm{L}(0.04 \mathrm{mmol})$ of triethylamine, and $4 \mathrm{mg}(0.03 \mathrm{mmol})$ of 4-(N,N-dimethylamino)pyridine in $0.5 \mathrm{~mL}$ of pyridine was stirred at room temperature for 17 h. The reaction mixture was concentrated to a residue, which was extracted into $3 \mathrm{~mL}$ of dichloromethane. The organic solution was washed with water (2 X $2 \mathrm{~mL}$ ), dried over anhydrous sodium sulfate, concentrated, and then chromatographed with 3:97 methanol / dichloromethane as the eluant to give $5 \mathrm{mg}\left(82 \%, 57 \%\right.$ overall from 15) of $\mathbf{1 7}$ as a syrup. ${ }^{1} \mathrm{H} \mathrm{NMR}\left(\mathrm{CDCl}_{3}, 300\right.$ MHz) $\delta 1.23$ (d, $J=6.3 \mathrm{~Hz}, 6 \mathrm{H}), 1.33$ (s, $9 \mathrm{H}), 1.84$ (ddd, $J=2.7,12.6,15.0 \mathrm{~Hz}, 1 \mathrm{H}), 2.12$ (s, 3 H), 2.26 (td, $J=3.6,15.0 \mathrm{~Hz}, 1 \mathrm{H}$ ), 3.89 (ddd, $J=2.1,3.0,10.2 \mathrm{~Hz}, 1 \mathrm{H}$ ), 4.03 (dd, $J=2.7,10.2$ Hz, 1 H), 4.32 (dd, $J=2.5,12.0$ Hz, 1 H), 5.05 (sept, $J=6.3$ Hz, 1 H), 5.58 (br q, $J=2.7$ Hz, 1 $\mathrm{H}), 5.78-5.80$ (m, $2 \mathrm{H}), 7.4-7.7$ (m, $3 \mathrm{H}), 7.85-8.08$ (m, $2 \mathrm{H}) ;{ }^{13} \mathrm{C} \mathrm{NMR}\left(\mathrm{CDCl}_{3}, 75 \mathrm{MHz}\right) \delta$ 21.6, 22.1, 27.5, 32.8, 39.7, 66.5, 69.3, 70.1, 73.3, 73.5, 74.5, 91.3, 127.7, 129.2, 131.8, 134.6, 169.1, 170.0, 176.8; FAB-MS m/z $503\left(\mathrm{MNa}^{+}\right)$. 


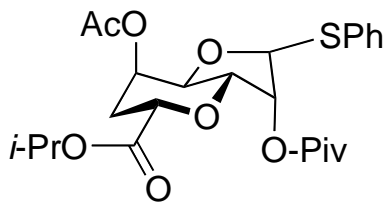

17

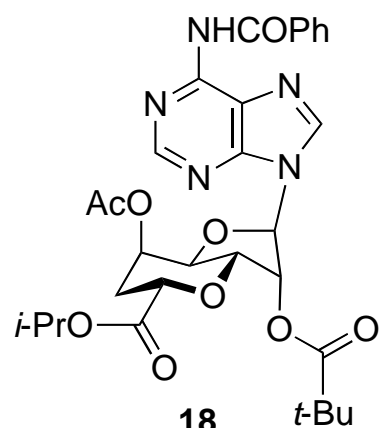

18

Compound 18. A solution of $5 \mathrm{mg}(0.021 \mathrm{mmol})$ of $\mathrm{N}_{6}$-benzoyladenine and $0.06 \mathrm{~mL}$ (0.25 mmol) of $\mathrm{N}, \mathrm{O}$-bis(trimethylsilyl)acetamide in $1.0 \mathrm{~mL}$ of dichloromethane was heated at reflux for $30 \mathrm{~min}$, then cooled to $0^{\circ} \mathrm{C}$. A solution of $6.0 \mathrm{mg}(0.012 \mathrm{mmol})$ of 17 in $0.1 \mathrm{~mL}$ of dichloromethane was added, followed by $7 \mathrm{mg}(0.031 \mathrm{mmol})$ of $N$-iodosuccinimide and $1.5 \mu \mathrm{L}$ $(0.017 \mathrm{mmol})$ of trifluoromethanesulfonic acid. The solution was stirred at room temperature for $6 \mathrm{~h}$, and then was quenched with aq sodium bisulfite and aq sodium bicarbonate. The organic layer was concentrated and then chromatographed on a preparatory silica plate with 1:19 methanol / dichloromethane as the eluant to afford $3 \mathrm{mg}(47 \%)$ of 18 as a colorless film. ${ }^{1} \mathrm{H}$ NMR $\left(\mathrm{CDCl}_{3}, 500 \mathrm{MHz}\right) \delta 1.29$ (d, $\left.J=6.4 \mathrm{~Hz}, 6 \mathrm{H}\right), 1.34$ (s, $\left.9 \mathrm{H}\right), 1.99$ (ddd, $J=2.5,12.6,14.9$ Hz, 1 H), 2.04 (s, 3 H), 2.35 (dt, $J=3.0,14.9$ Hz, 1 H), 4.04 (dd, $J=2.6,10.2$ Hz, 1 H), 4.58 (dd, $J=2.7,12.3 \mathrm{~Hz}, 1 \mathrm{H}$ ), 4.96 (dd, $J=5.2,10.1 \mathrm{~Hz}, 1 \mathrm{H}$ ), 5.12 (sept, $J=6.3 \mathrm{~Hz}, 1 \mathrm{H}$ ), 5.70 (br q, $J$ $=2.5 \mathrm{~Hz}, 1 \mathrm{H}), 5.80(\mathrm{~d}, J=5.2 \mathrm{~Hz}, 1 \mathrm{H}), 6.01(\mathrm{~s}, 1 \mathrm{H}), 7.56(\mathrm{t}, J=7.3 \mathrm{~Hz}, 2 \mathrm{H}), 7.65$ (t, $J=7.3$ Hz, 1 H), 8.05 (d, J = 7.3 Hz, 2 H), 8.09 (s, 1 H), 8.84 (s, 1 H), 9.02 (br s, 1 H); ${ }^{13} \mathrm{C} \mathrm{NMR}$ $\left(\mathrm{CDCl}_{3}, 150 \mathrm{MHz}\right) \delta 21.2,21.9,27.4,29.9,32.3,39.3,66.1,69.4,71.9,73.3,73.7,76.7,89.6$, 123.7, 128.0, 129.2, 133.1, 133.7, 142.1, 150.0, 151.4, 153.1, 164.7, 169.1, 170.1, 177.5 ; LCMS m/z $610\left(\mathrm{MH}^{+}\right), 371\left(\mathrm{M}^{+}-N\right.$-benzoyladeninyl).

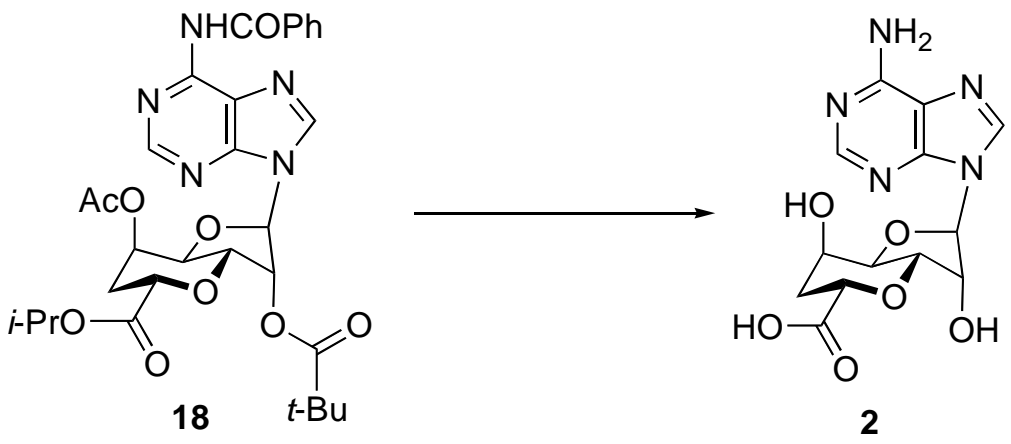


“Octosyl Adenine,” 2. A solution of $1.62 \mathrm{mg}(0.0026 \mathrm{mmol})$ of $\mathbf{1 8}$ in $0.05 \mathrm{~mL}$ of methanol and $0.05 \mathrm{~mL}$ of $1.0 \mathrm{M}$ aq lithium hydroxide was stirred for $1.5 \mathrm{~h}$ at room temperature. The solution was neutralized with $0.050 \mathrm{~mL}$ of $1.0 \mathrm{M}$ aqueous hydrochloric acid and then concentrated to give the $N$-benzoyl derivative (containing lithium salts), which was characterized spectroscopically. ${ }^{1} \mathrm{H}$ NMR $\left(\mathrm{D}_{2} \mathrm{O}, 500 \mathrm{MHz}\right) \delta 1.80$ (ddd, $\left.J=2.3,12.4,14.6 \mathrm{~Hz}, 1 \mathrm{H}\right), 2.25$ (td, $J$ = 3.2, $14.6 \mathrm{~Hz}, 1 \mathrm{H}$ ), 4.16 (dd, $J=2.0,10.3 \mathrm{~Hz}, 1 \mathrm{H}$ ), 4.39 (dd $J=4.5,10.2 \mathrm{~Hz}, 1 \mathrm{H}$ ), 4.45 (dd, $J$ = 2.5, 12.4 Hz, $1 \mathrm{H}$ ), 4.54 (d, $J=4.6 \mathrm{~Hz}, 1 \mathrm{H}, 4.6-5.1$ (obscured by HOD), 6.11 (s, $1 \mathrm{H}), 7.57$ (t, $J=7.5 \mathrm{~Hz}, 2 \mathrm{H}), 7.66$ (t, $J=7.4 \mathrm{~Hz}, 1 \mathrm{H}), 8.01$ (d, $J=7.3 \mathrm{~Hz}, 2 \mathrm{H}), 8.69$ (s, $1 \mathrm{H}), 8.73$ (s, $1 \mathrm{H}$ ); LC-MS m/z $448\left(\mathrm{MLi}^{+}\right), 442\left(\mathrm{MH}^{+}\right)$.

The crude $N$-benzoyl derivative from above was dissolved in $0.10 \mathrm{~mL}$ of concentrated aq ammonia and allowed to stir for $12 \mathrm{~h}$. Concentration under vacuum gave a residue that was washed sequentially with $1 \mathrm{~mL}$ of ethyl acetate, then $1 \mathrm{~mL}$ each of 1:19, 1:9, and 3:17 methanol / ethyl acetate (to remove lithium carboxylate and chloride salts), affording $0.66 \mathrm{mg}$ (74\% overall from 18) of 2. ${ }^{1} \mathrm{H}$ NMR ( $\mathrm{CD}_{3} \mathrm{OD}, 600 \mathrm{MHz}$, assignments by HSQC and HMBC) $\delta 1.85$ (ddd, $J=$ 2.3, 12.6, $14.8 \mathrm{~Hz}, \mathrm{H}-6$ ' ${ }_{\text {ax }}$ ), 2.22 (td, $J=3.2,14.8 \mathrm{~Hz}, \mathrm{H}-6$ ' ${ }_{\text {eq }}$ ), 4.13 (dd, $J=2.5,10.4 \mathrm{~Hz}, \mathrm{H}-4^{\prime}$ ), 4.30 (dd, $J=4.8,10.3$ Hz, H-3’), 4.40 (dd, $J=2.7,12.6$ Hz, H-7'), 4.60 (d, $J=4.8$ Hz, H-2'), 4.64 (br q, $J=2.7$ Hz, H-5'), 6.14 (s, H-1'), 8.23 (s, H-2), 8.28 (s, H-8); ${ }^{13}$ C NMR (D ${ }_{2} \mathrm{O}$, protondetected at $600 \mathrm{MHz}$, assignments by HSQC and HMBC) $\delta 34.8$ (C-6’), 64.5 (C-5’), 70.8 (C-3’), 72.9 (C-2’), 75.2 (C-7’), 77.7 (C-4’), 90.8 (C-1'), 119.1 (C-5), 139.6 (C-8), 148.5 (C-4), 152.8 (C-2), 155.7 (C-6), $\underline{\mathrm{C}}=\mathrm{O}$ not observed; LC-MS m/z $338\left(\mathrm{MH}^{+}\right)$.

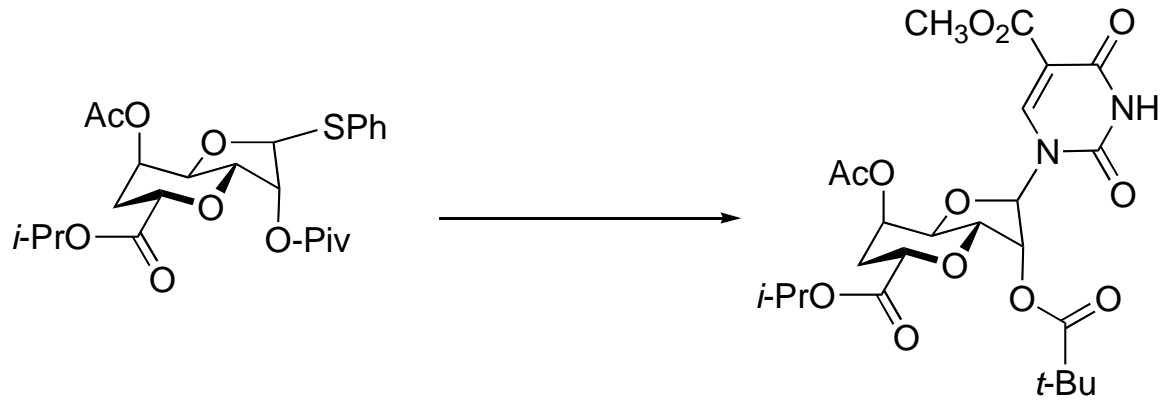

17

19

Compound 19. A solution of freshly distilled methyl 2,4bis(trimethylsilyloxy)pyrimidine-5-carboxylate (0.026 g, $0.082 \mathrm{mmol})$ and $0.017 \mathrm{~g}(0.075 \mathrm{mmol})$ of $N$-iodosuccinimide in $0.5 \mathrm{ml}$ dichloromethane was added to a solution of $12 \mathrm{mg}(0.025 \mathrm{mmol})$ 
of 17 in $0.5 \mathrm{ml}$ dichloromethane, followed by $4 \mu \mathrm{L}(0.038 \mathrm{mmol})$ of trifluoromethanesulfonic acid. The solution was stirred at room temperature for $2 \mathrm{~h}$, and then was quenched with 10\% aq sodium thiosulfate. The aqueous phase was washed with dichloromethane ( $3 \mathrm{X} 5 \mathrm{~mL}$ ), and the combined organic extract was concentrated and then chromatographed on a preparatory silica plate with 7:93 methanol/dichloromethane as the eluant to give $9.2 \mathrm{mg}$ (contaminated with succinimide, 2.81 and $29.6 \mathrm{ppm})$ of 19. ${ }^{1} \mathrm{H} \mathrm{NMR}\left(\mathrm{CDCl}_{3}, 500 \mathrm{MHz}\right) \delta 1.27$ (d, $\left.J=6.1 \mathrm{~Hz}, 6 \mathrm{H}\right)$, 1.31 (s, 9 H), 1.92 (ddd, $J=2.3,12.6,14.6 \mathrm{~Hz}, 1 \mathrm{H}$ ), 2.27 (s, $3 \mathrm{H}$ ), 2.36 (td, $J=2.7,15.1 \mathrm{~Hz}, 1$ H), 3.91 (s, 3 H), 3.97 (dd, $J=2.5,10.3$ Hz, 1 H), 4.15 (dd, $J=5.5,10.2$ Hz, 1 H), 4.42 (dd, $J=$ 2.4, $12.2 \mathrm{~Hz}, 1 \mathrm{H}$ ), 5.09 (sept, $J=6.2 \mathrm{~Hz}, 1 \mathrm{H}$ ), 5.48 (d, $J=5.5 \mathrm{~Hz}, 1 \mathrm{H}$ ), 5.70 (br q, $J=2.5 \mathrm{~Hz}$, $1 \mathrm{H}$ ), 5.82 (s, $1 \mathrm{H}), 8.04$ (br s, $1 \mathrm{H}), 8.38$ (s, $1 \mathrm{H}) ;{ }^{13} \mathrm{C} \mathrm{NMR}\left(\mathrm{CDCl}_{3}, 150 \mathrm{MHz}\right) \delta$ 21.3, 21.9, 27.3, 32.3, 39.2, 52.9, 66.2, 69.5, 71.7, 72.8, 73.7, 76.6, 91.6, 106.2, 147.8, 148.5, 158.1, 163.5, 168.8, 170.5, 177.0; FAB-MS m/z $563\left(\mathrm{MNa}^{+}\right), 1103\left(\mathrm{M}_{2} \mathrm{Na}^{+}\right)$.
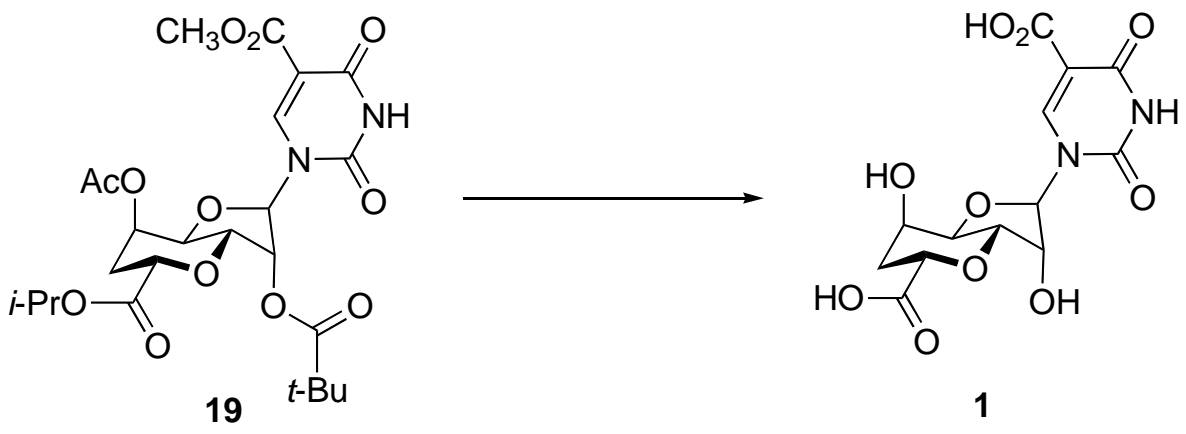

Octosyl Acid A (1). A solution of $7.7 \mathrm{mg}(0.014 \mathrm{mmol})$ of 19 in $0.4 \mathrm{~mL}$ of methanol and $0.3 \mathrm{~mL}$ of $1.0 \mathrm{M}$ aq lithium hydroxide was stirred at room temperature for $1 \mathrm{~h}$. The $\mathrm{pH}$ of the solution was brought to approximately 6.8 (monitored by $\mathrm{pH}$ paper) by addition of $2.0 \mathrm{M}$ aq hydrochloric acid (about $0.15 \mathrm{~mL}$ total). The solution was concentrated and then dried by azeotropic coevaporation with toluene ( 3 X $5 \mathrm{~mL}$ ). The resulting white solid residue was washed sequentially with ethyl acetate, 1:9 methanol / ethyl acetate, 3:7 methanol / ethyl acetate, and finally 3:2 methanol / ethyl acetate to remove organic byproducts (lithium acetate, lithium pivaloate and inorganic lithium salts). The remaining residue (2.9 mg, 58\%) consisted of octosyl acid A dilithium salt, neutralized for NMR analysis. ${ }^{1} \mathrm{H}$ NMR (DMSO- $\mathrm{d}_{6}$, TFA, $600 \mathrm{MHz}$, assignments by NOESY, HSQC and HMBC) $\delta 1.75$ (ddd, $J=2.0,12.2,14.4 \mathrm{~Hz}, \mathrm{H}-6$ ' ${ }_{\text {ax }}$ ), 1.93 (td, $J=3.1,14.4$ Hz, H-6' ' eq), 3.68 (dd, $J=4.5,10.0$ Hz, H-3’), 3.92 (dd, $J=1.5,10.3$ Hz, H-4'), 4.23 (t, $J=3.7$ Hz, H-2’), 4.29 (dd, $J=2.7,12.2$ Hz, H-7’), 4.43 (br s, H-5’), 5.55 (s, H-1'), 5.73 
(d, $J=2.5 \mathrm{~Hz}, 5$ '- $-\underline{\mathrm{H}}$ ), 5.93 (d, $J=4.0 \mathrm{~Hz}, 2^{\prime}-\mathrm{O} \underline{\mathrm{H}}$ ), 9.03 (s, H-6), 12.20 (s, NH), 12.71 (br s, 2 $\mathrm{CO}_{2} \underline{\mathrm{H}}$ ); ${ }^{13} \mathrm{C}$ NMR (DMSO- $\mathrm{d}_{6}$, TFA, proton-detected at $600 \mathrm{MHz}$, assignments by HSQC and HMBC) $\delta 35.8$ (C-6’), 63.9 (C-5’), 71.5 (C-3’), 72.2 (C-2'), 73.2 (C-7’), 78.3 (C-4'), 92.9 (C1'), 148.9 (C-6), 149.8 (C-2), 163.3 (C-4), 165.2 (5- $\left.\mathrm{CO}_{2} \mathrm{H}\right), 172.4$ (8'- $\left.\mathrm{CO}_{2} \mathrm{H}\right), \mathrm{C}-5$ not observed; LC-MS m/z $338\left(\mathrm{MH}^{+}\right)$. 
WUT SAB/CDC13/300RHz

pulse sequencer s2pur
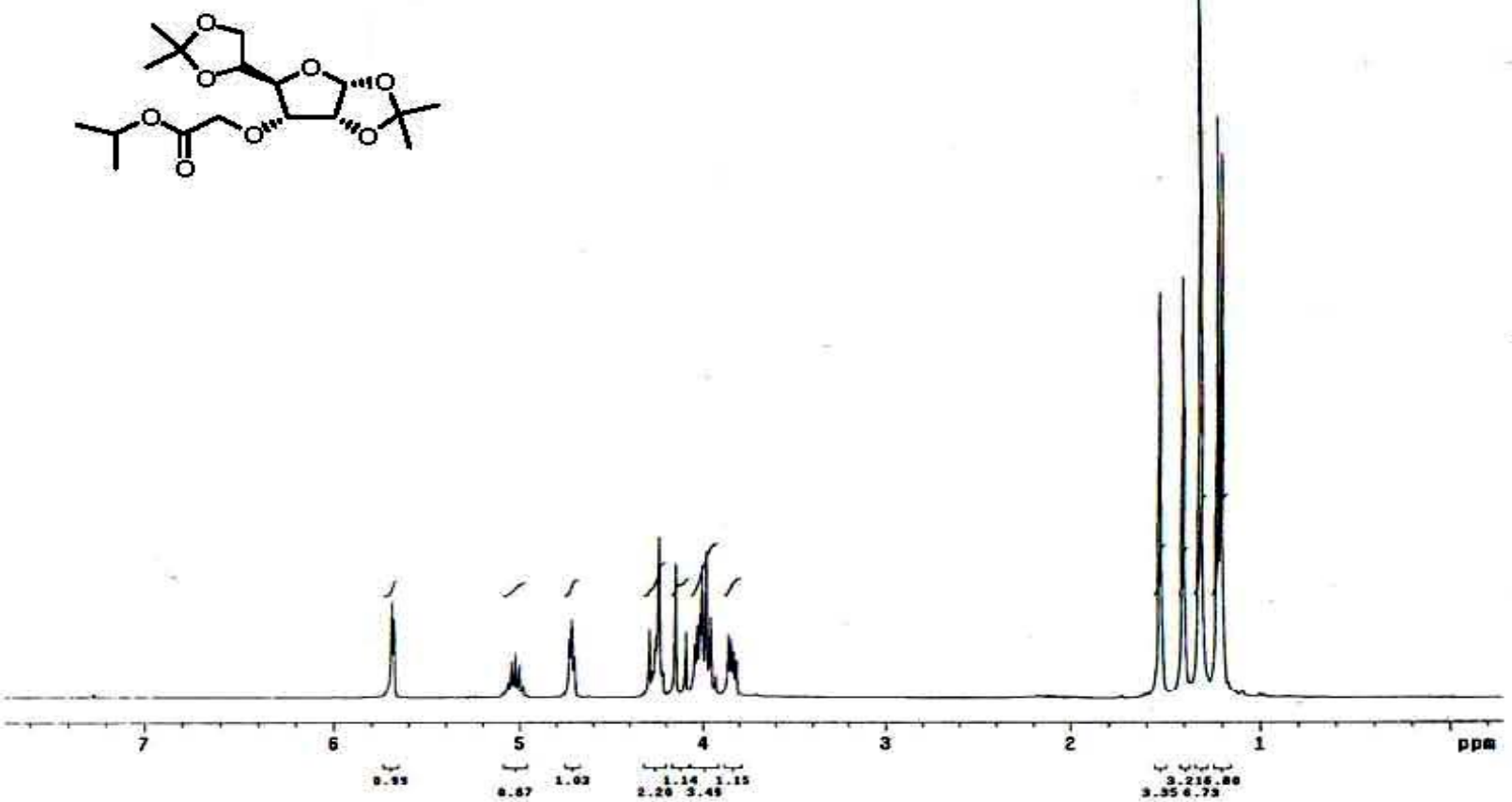

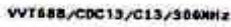

putse sequencer szpul
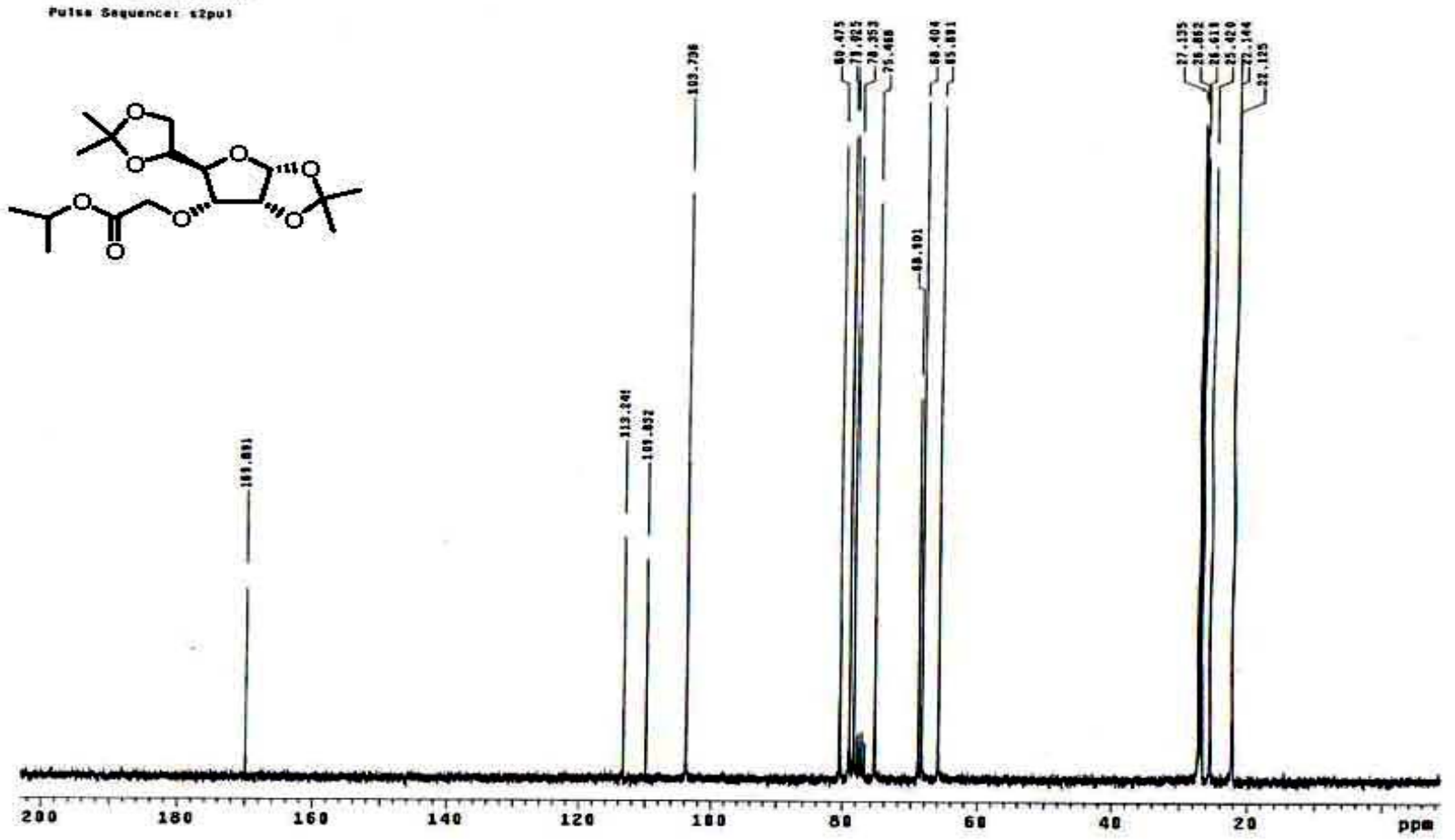

${ }^{1} \mathrm{H}$ and ${ }^{13} \mathrm{C}$ NMR of compound $6\left(\mathrm{CDCl}_{3}\right)$ 
wriserefcucis/somentz Pulse sequence: s2bur<smiles>CC(C)OC(=O)CO[C@H]1[C@H](C(O)CO)O[C@@H]2OC(C)(C)O[C@H]12</smiles>
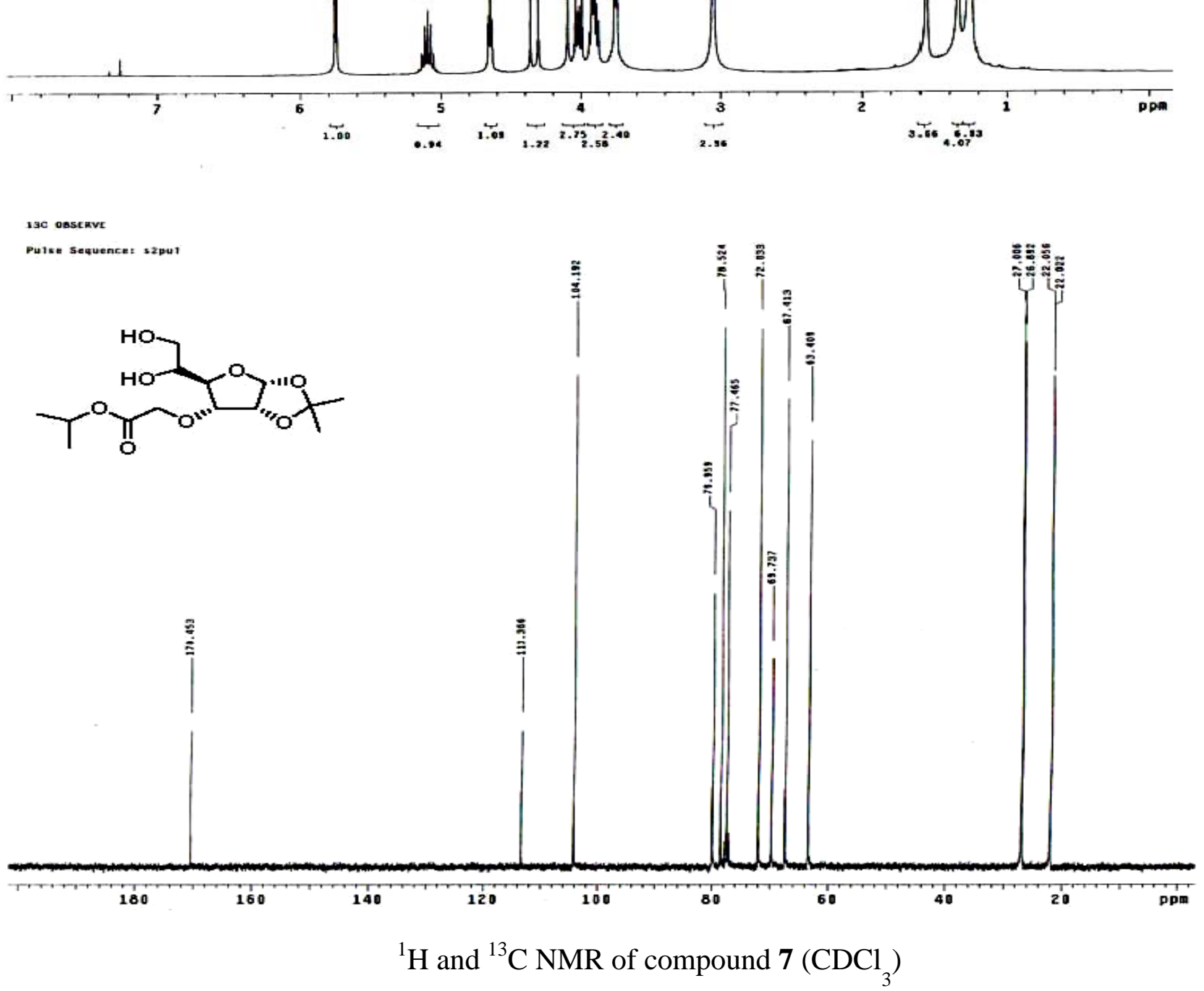

$$
13 \mathrm{c} \text { osseave }
$$




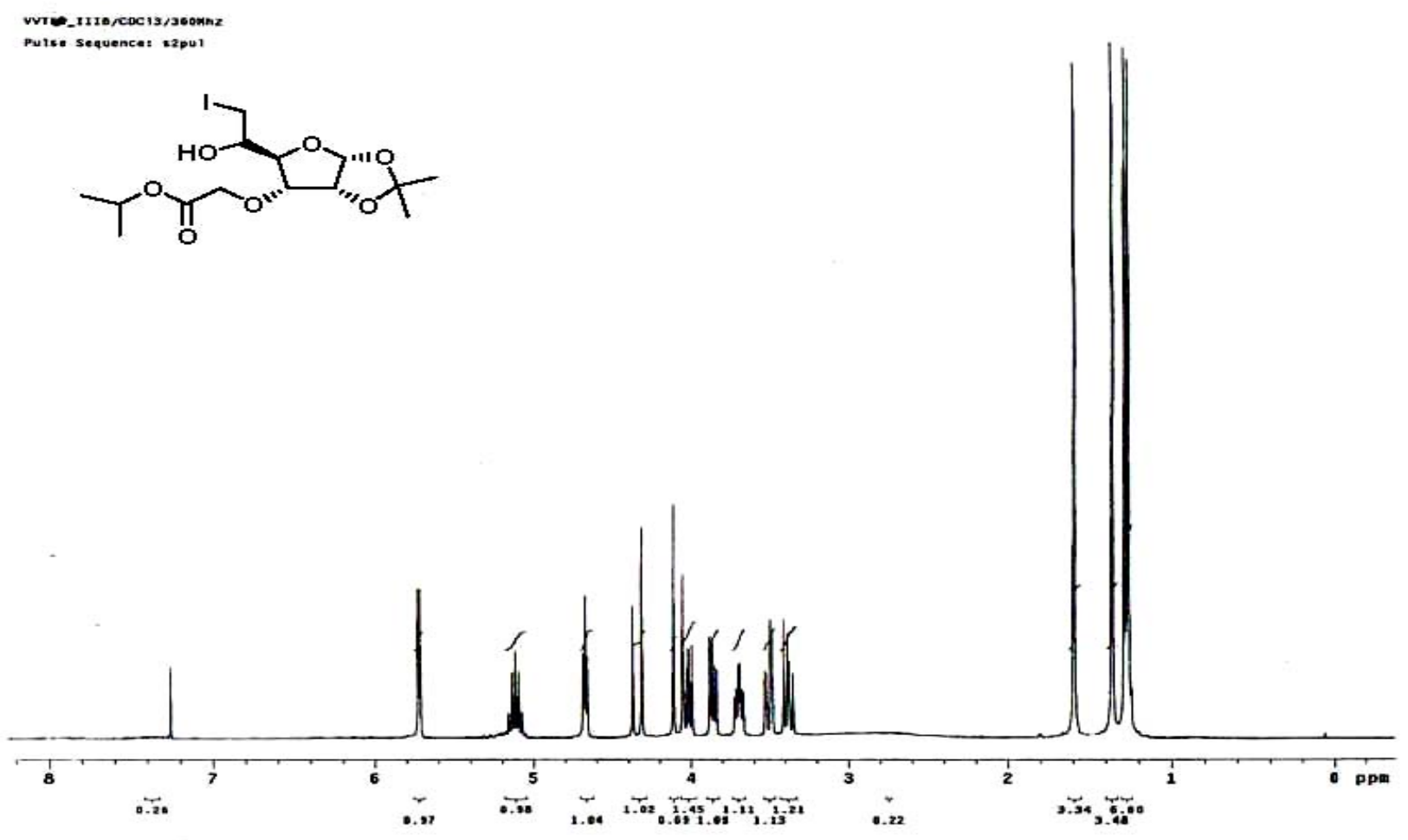

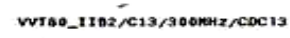
pulse sequencet szpur

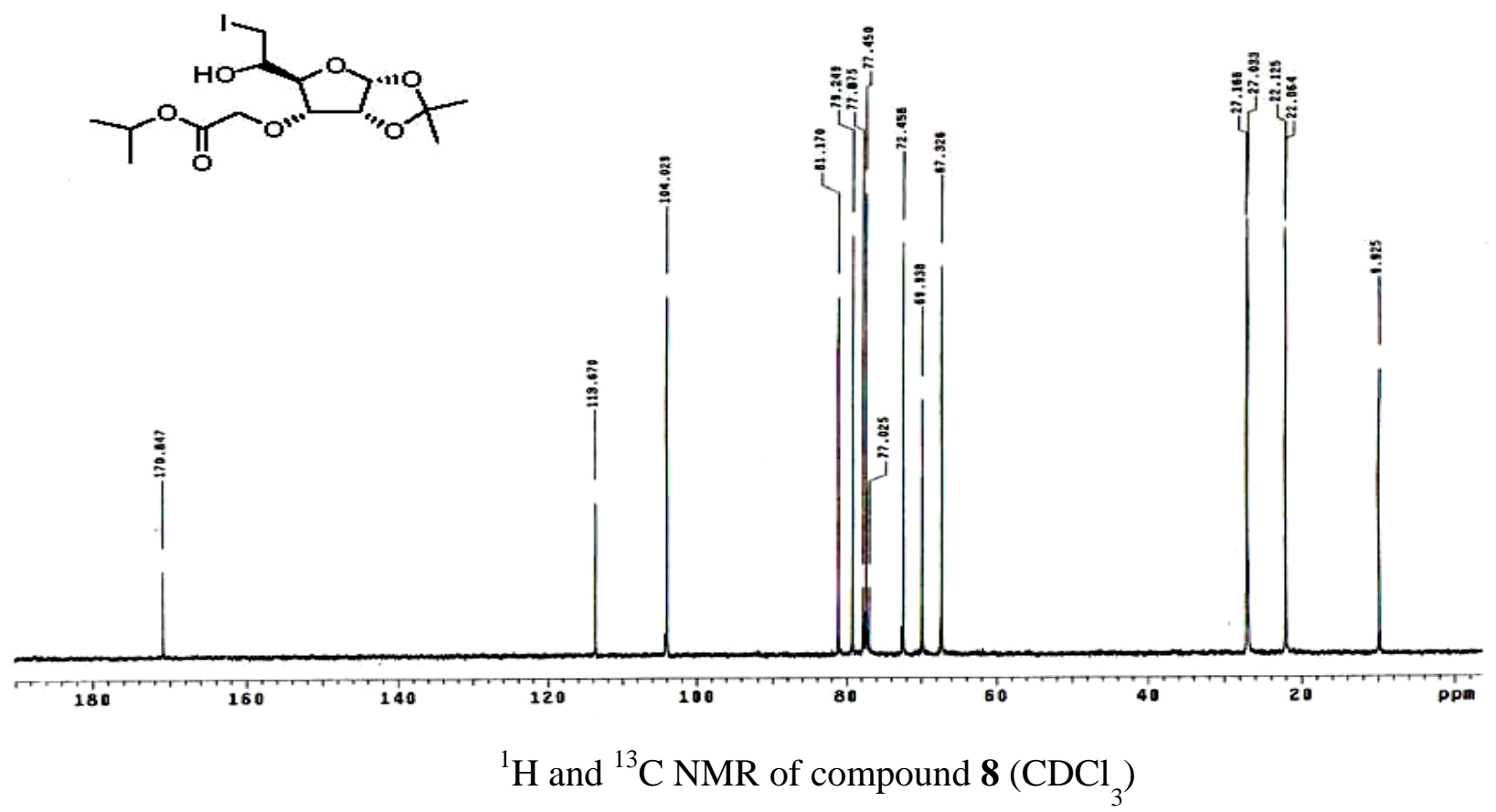



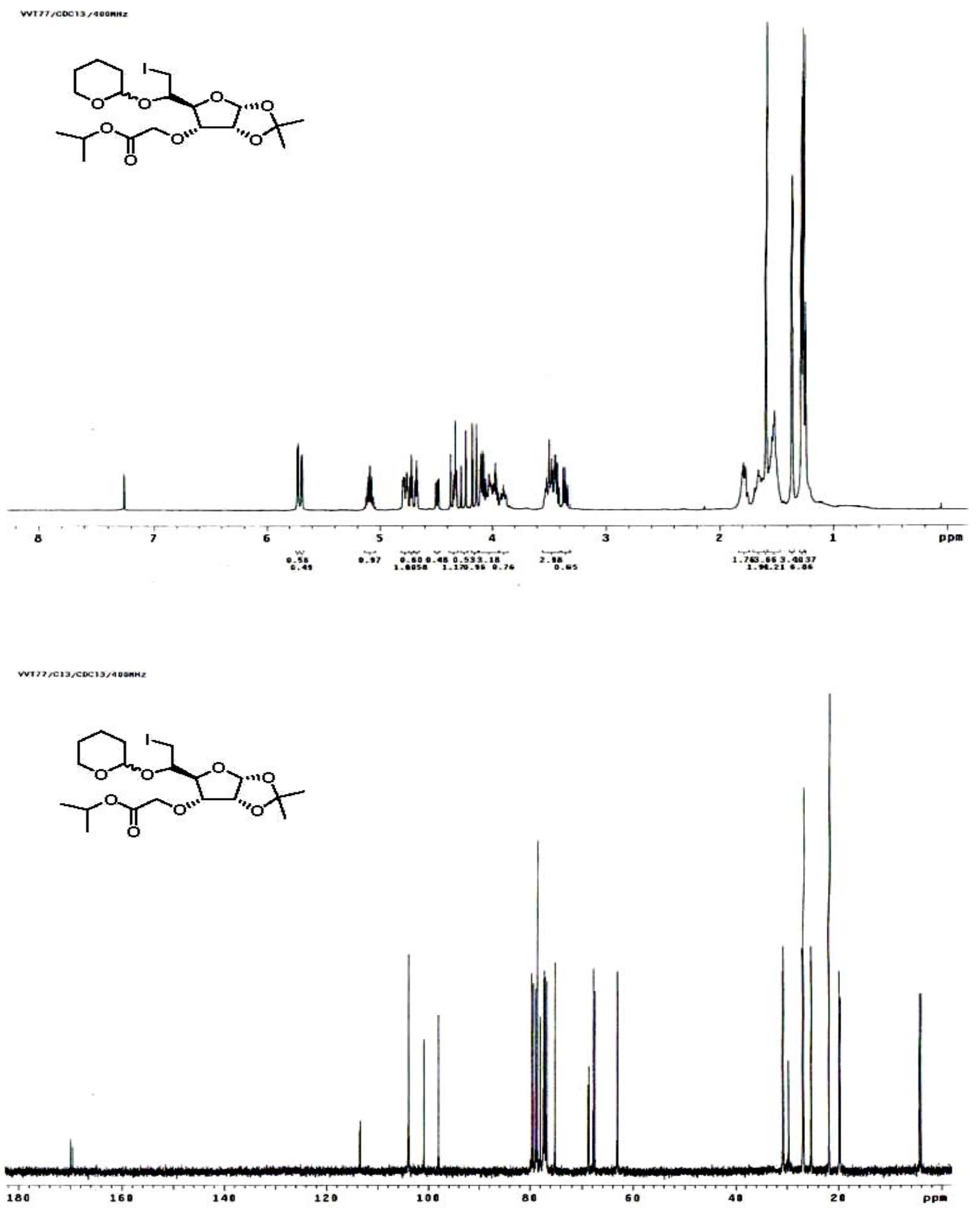

${ }^{1} \mathrm{H}$ and ${ }^{13} \mathrm{C}$ NMR of compound $\mathbf{9}\left(\mathrm{CDCl}_{3}\right)$ 
Knapp et al, "Short Synthesis of Octosyl Nucleosides"

VWT_DNC_A,CDC19/40 016H X
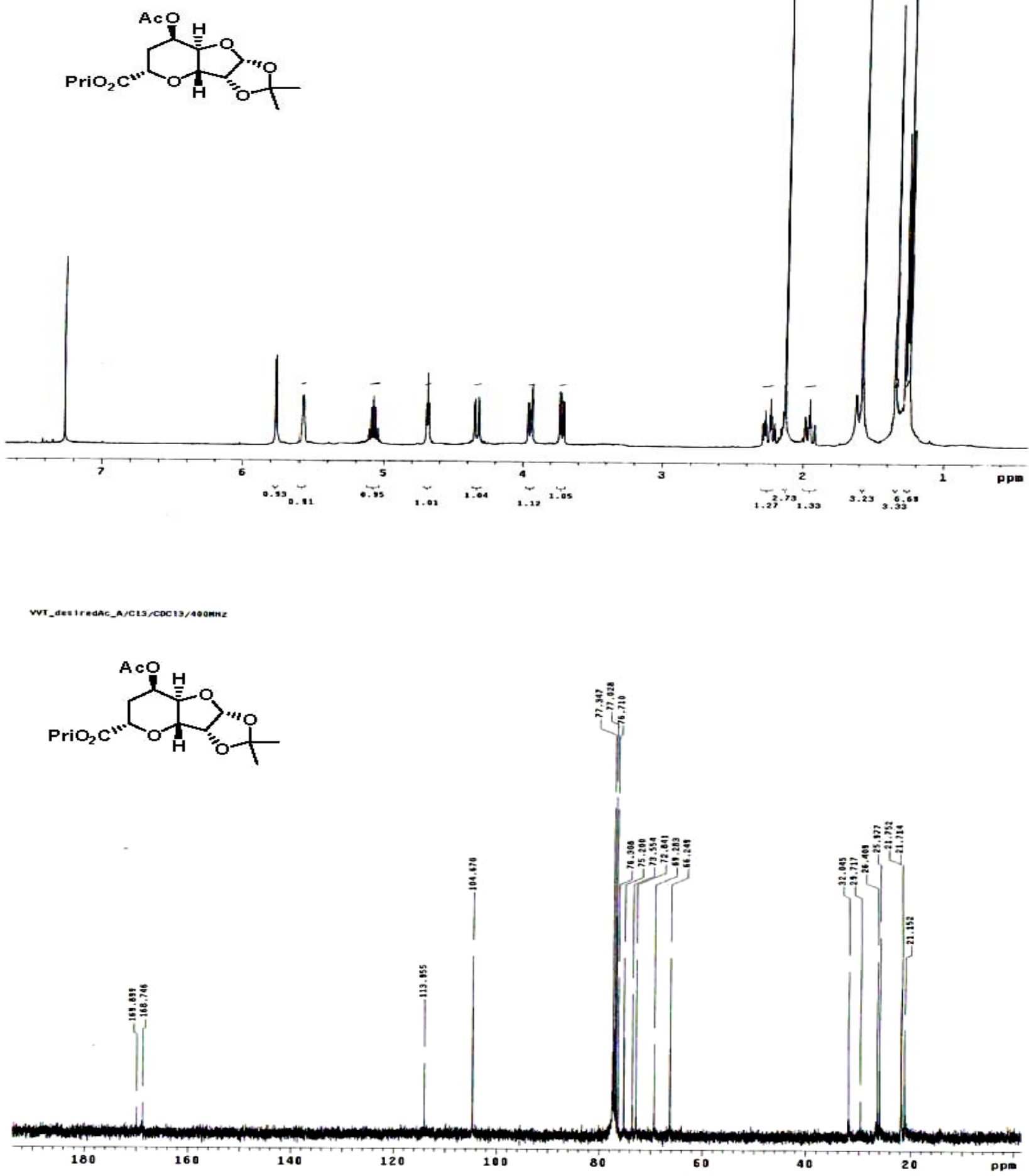

${ }^{1} \mathrm{H}$ and ${ }^{13} \mathrm{C}$ NMR of compound $12\left(\mathrm{CDCl}_{3}\right)$

S-16 

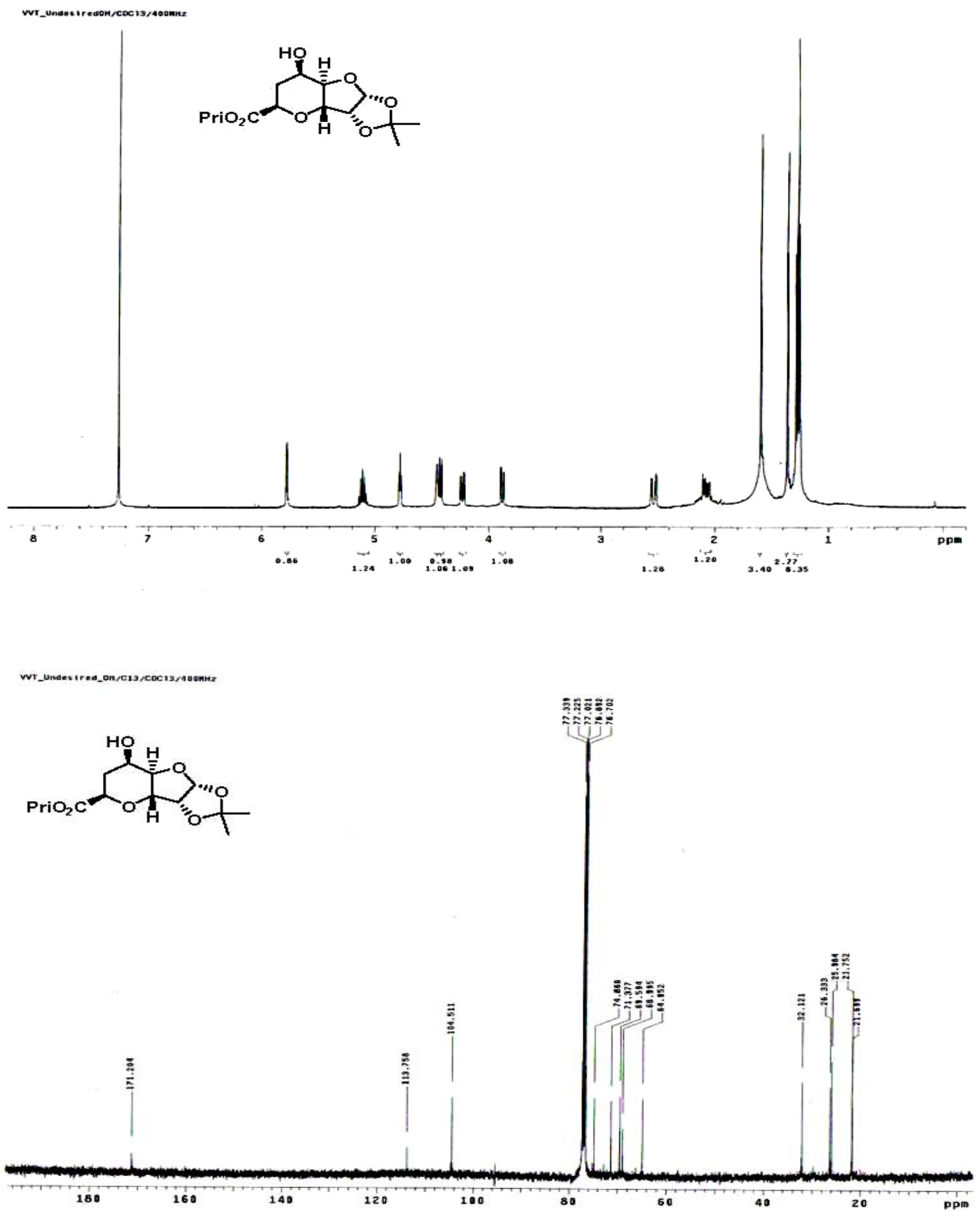

${ }^{1} \mathrm{H}$ and ${ }^{13} \mathrm{C}$ NMR of compound $\mathbf{1 3}\left(\mathrm{CDCl}_{3}\right)$ 


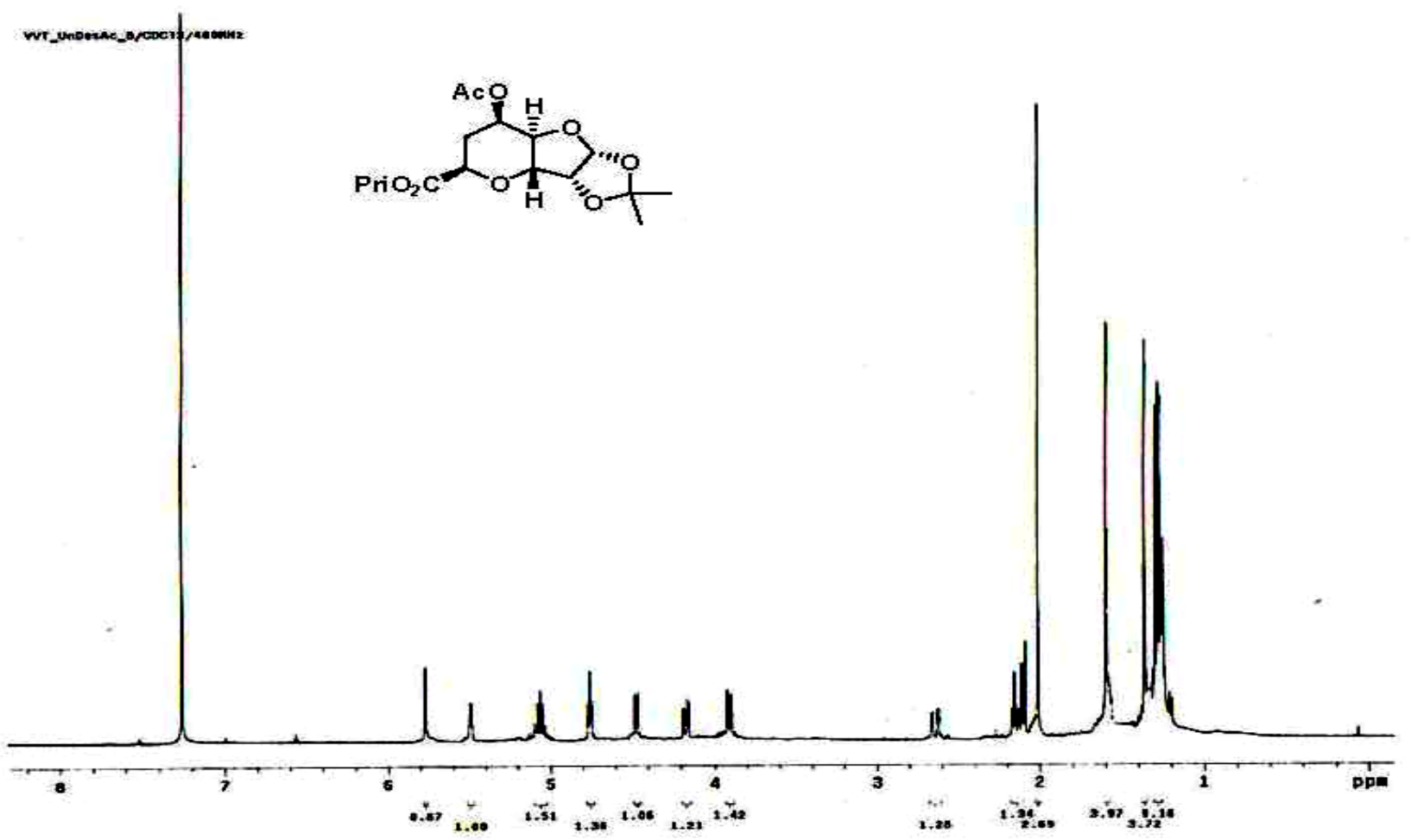

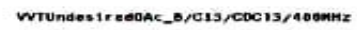

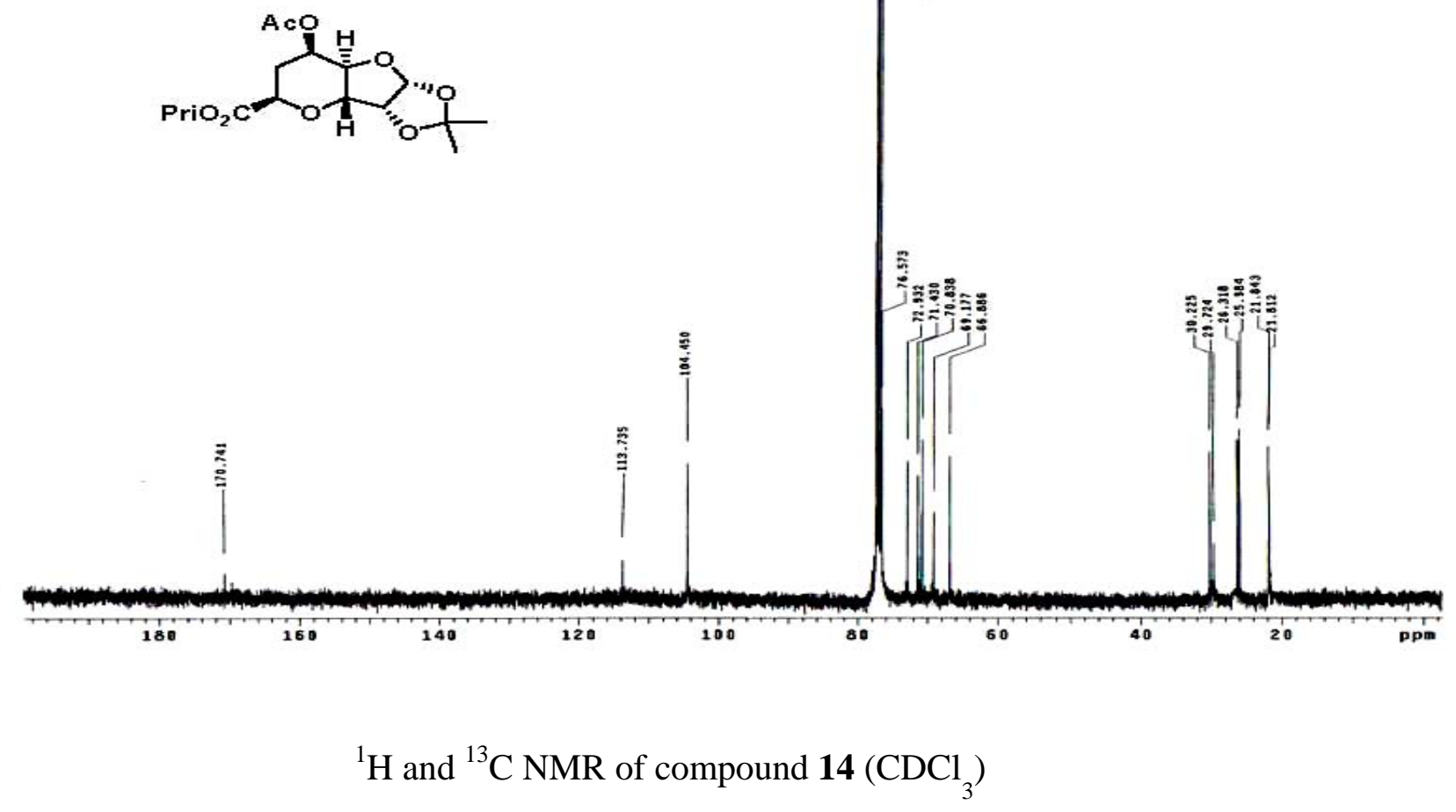


Knapp et al, "Short Synthesis of Octosyl Nucleosides"

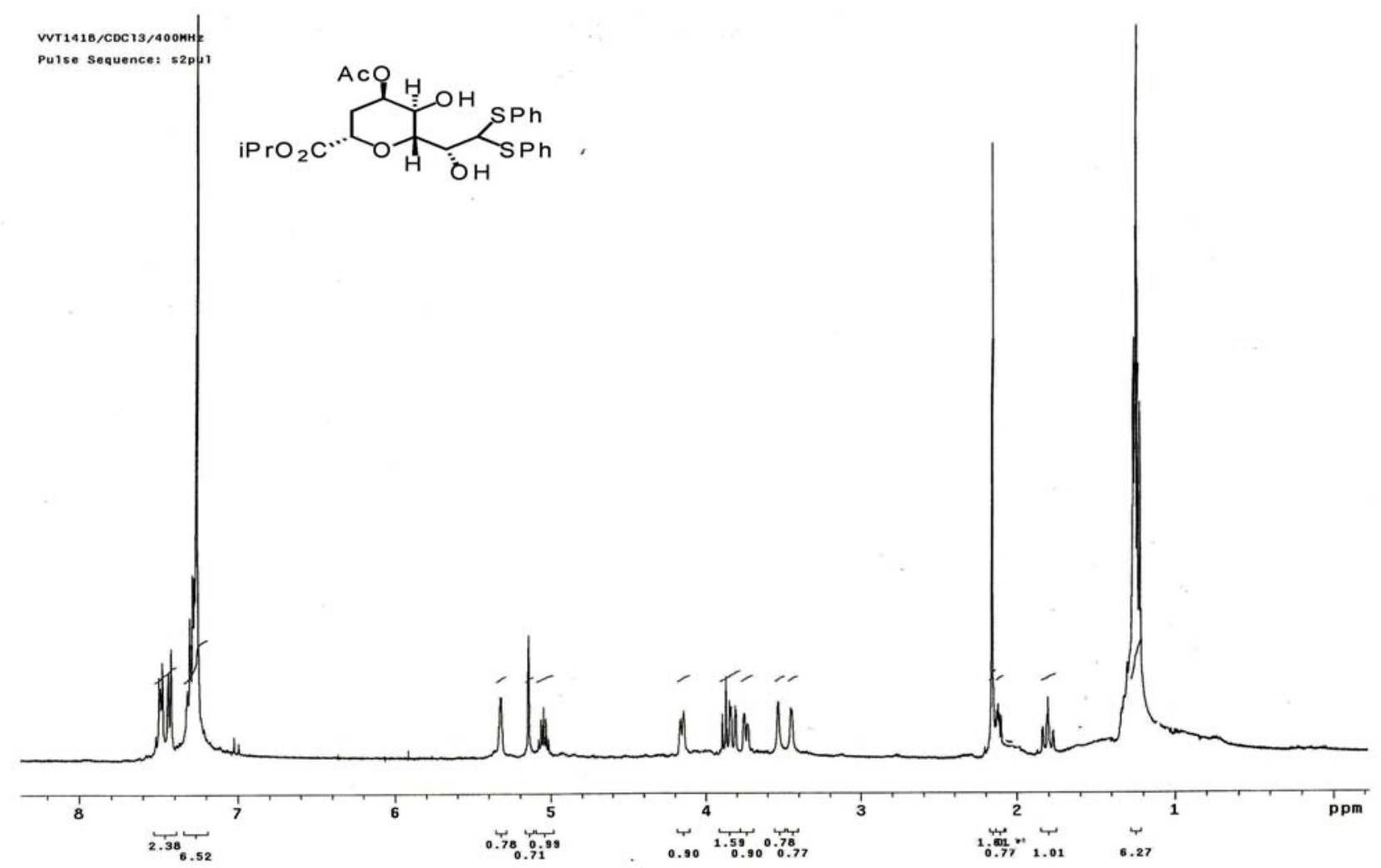

NVTHA1B,

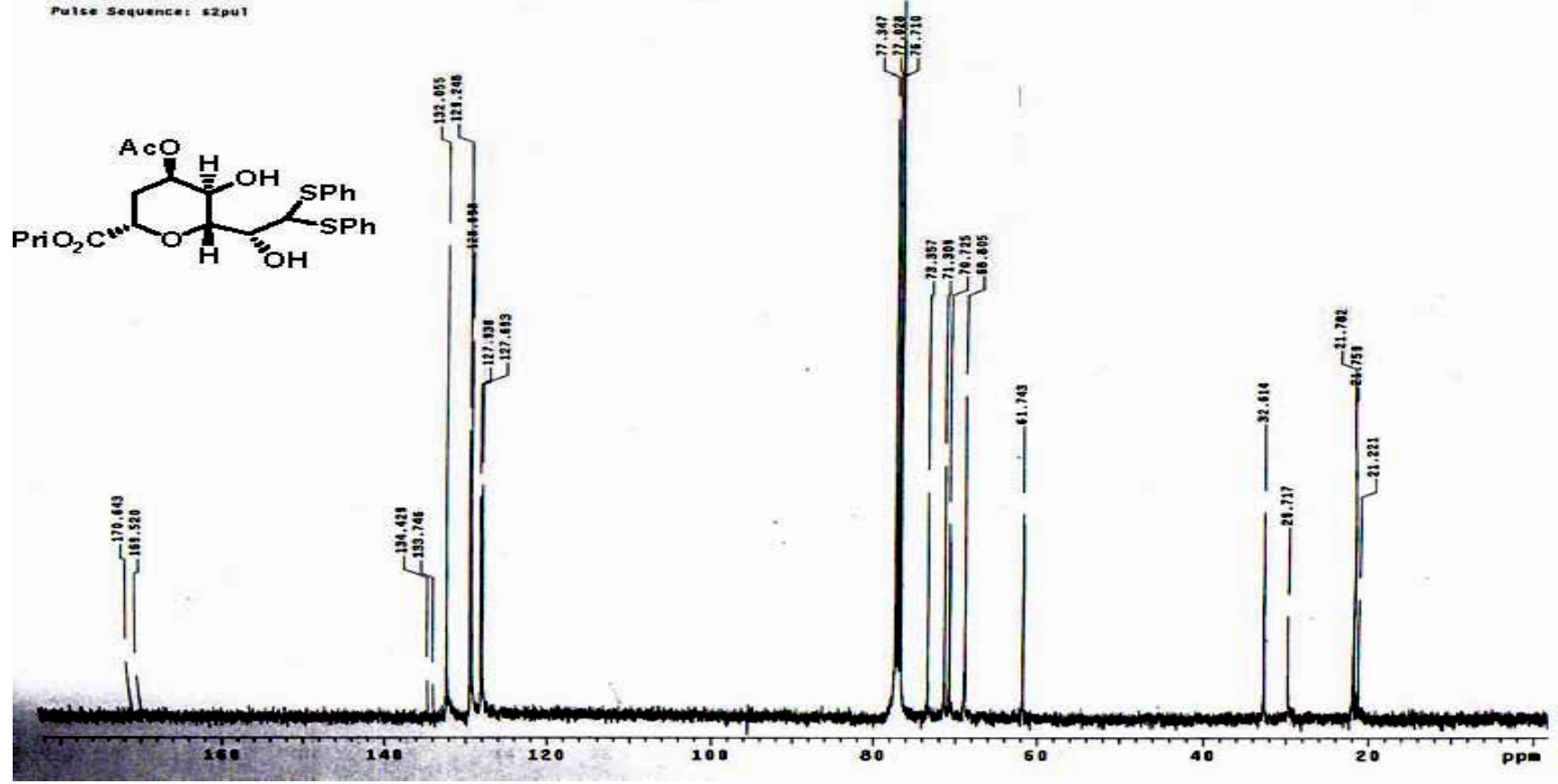

${ }^{1} \mathrm{H}$ and ${ }^{13} \mathrm{C}$ NMR of compound $\mathbf{1 5}\left(\mathrm{CDCl}_{3}\right)$ 

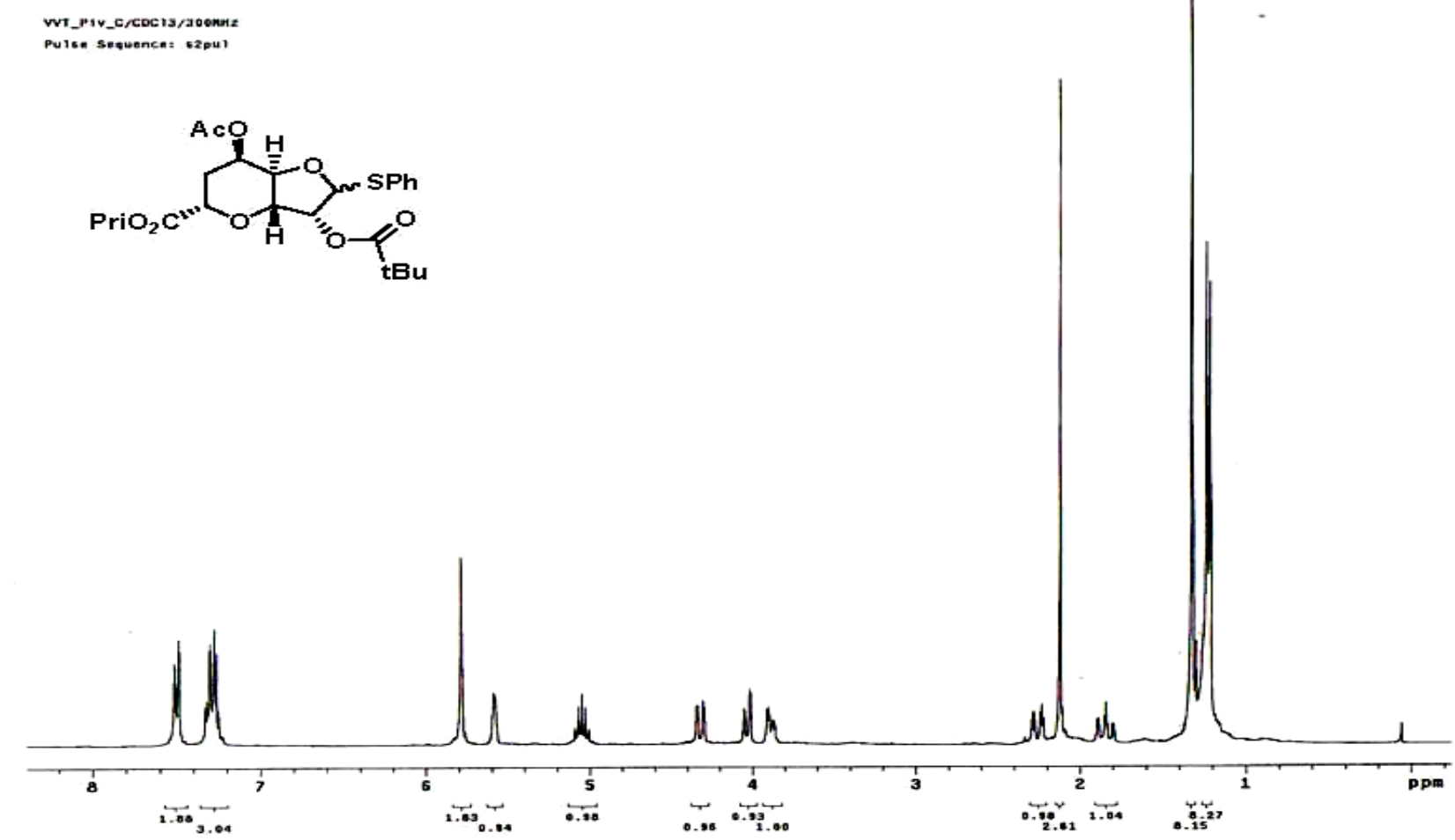

wripine, COC 13/300miz Puise sequence: szpul

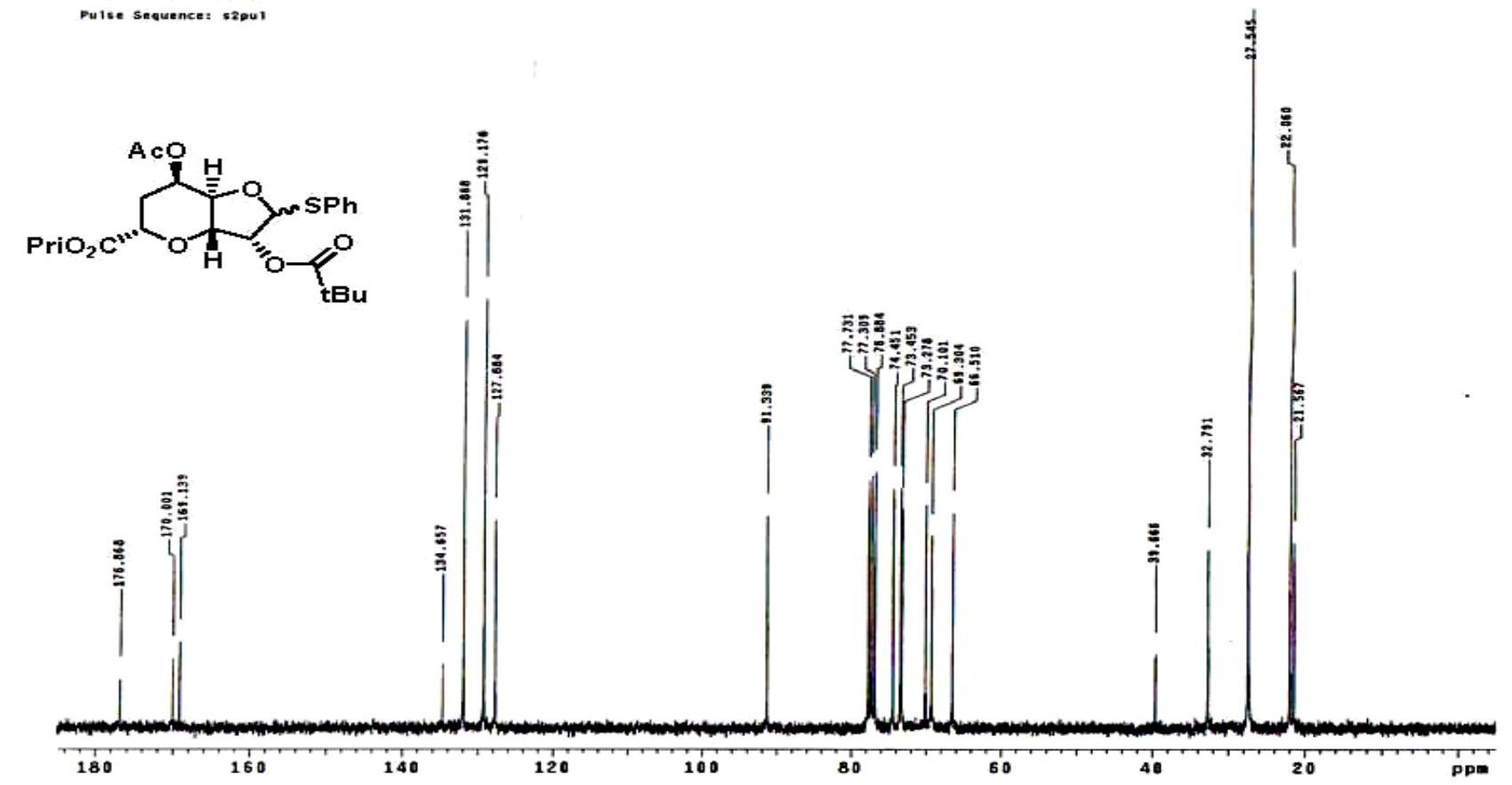

\footnotetext{
${ }^{1} \mathrm{H}$ and ${ }^{13} \mathrm{C}$ NMR of compound $\mathbf{1 7}\left(\mathrm{CDCl}_{3}\right)$
} 


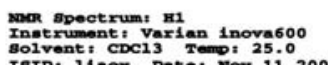

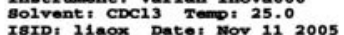

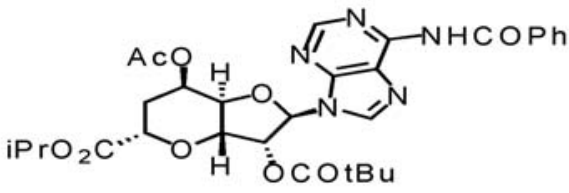
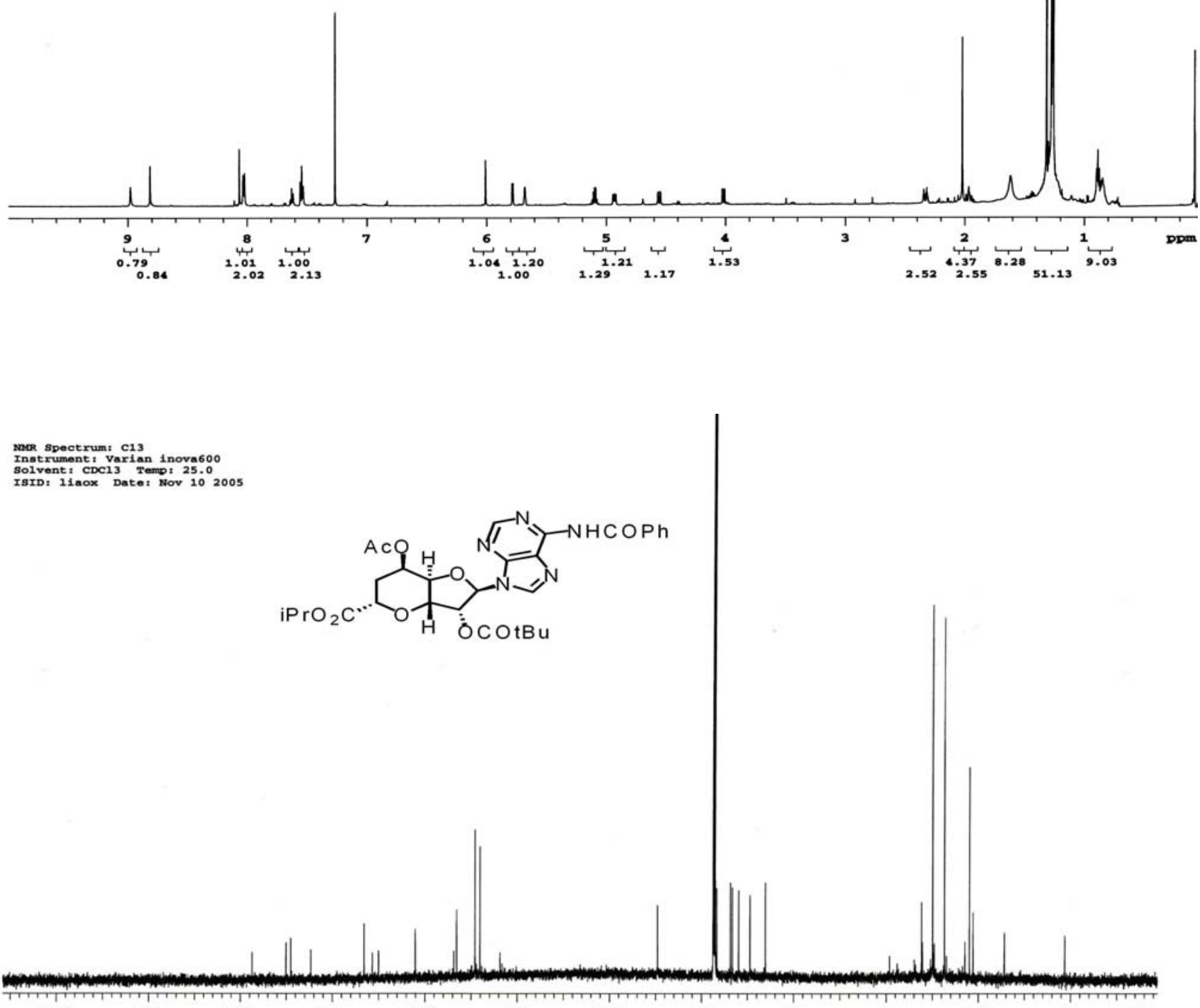

160

140

120

${ }^{1} \mathrm{H}$ and ${ }^{13} \mathrm{C}$ NMR of compound $\mathbf{1 8}\left(\mathrm{CDCl}_{3}\right)$ 


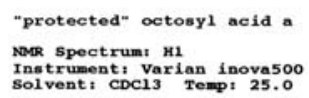<smiles>COCc1cn(C2OC3C(O[14CH3])C[C@@H](COOC(C)C)OC3[C@H](O)C2O)c(=O)[nH]c1=O</smiles>

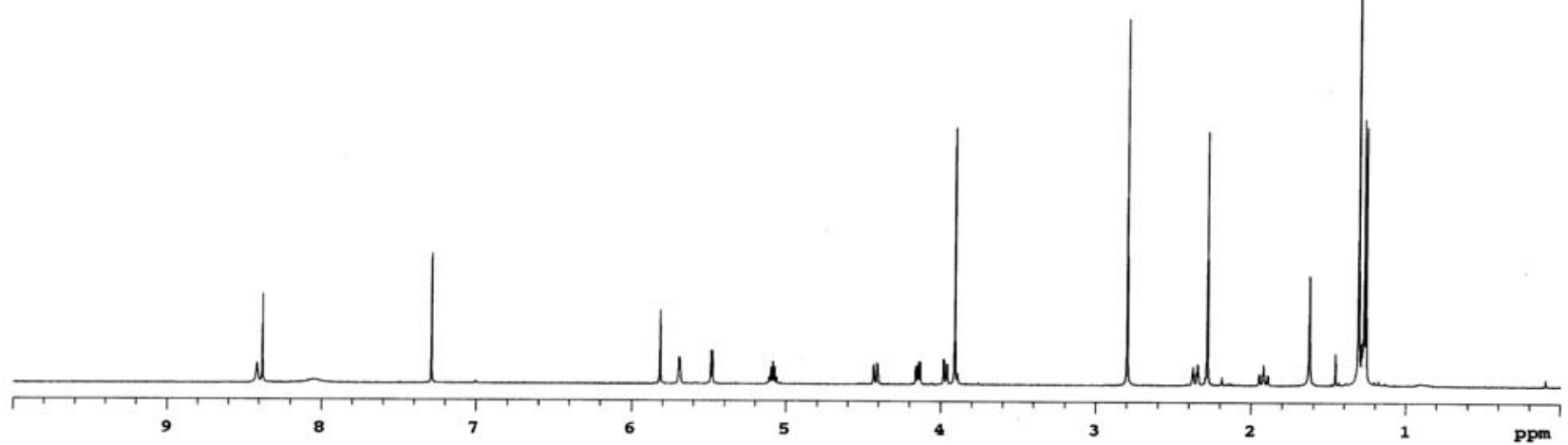

"protectod" octony1 acid a

Nare spect rum: C13

Solvent: CDC13 Tomp: 25.0

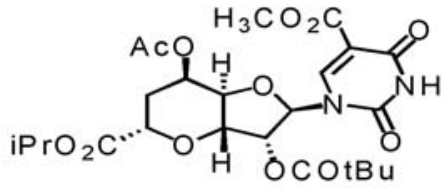

ता?

160

${ }^{1} \mathrm{H}$ and ${ }^{13} \mathrm{C}$ NMR of compound $19\left(\mathrm{CDCl}_{3}\right)$ 

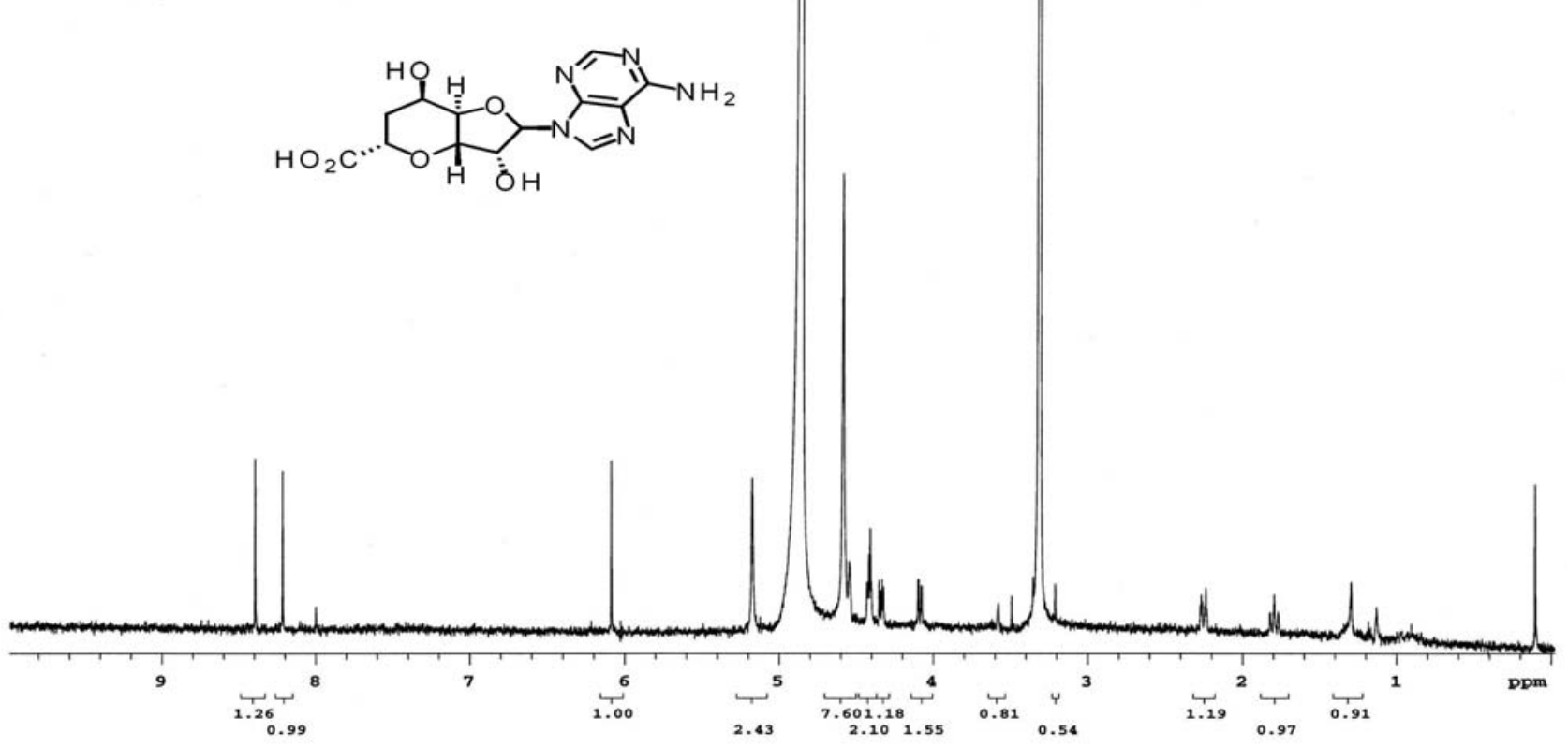

${ }^{1} \mathrm{H}$ NMR of compound $2\left(\mathrm{CD}_{3} \mathrm{OD}\right)$ 


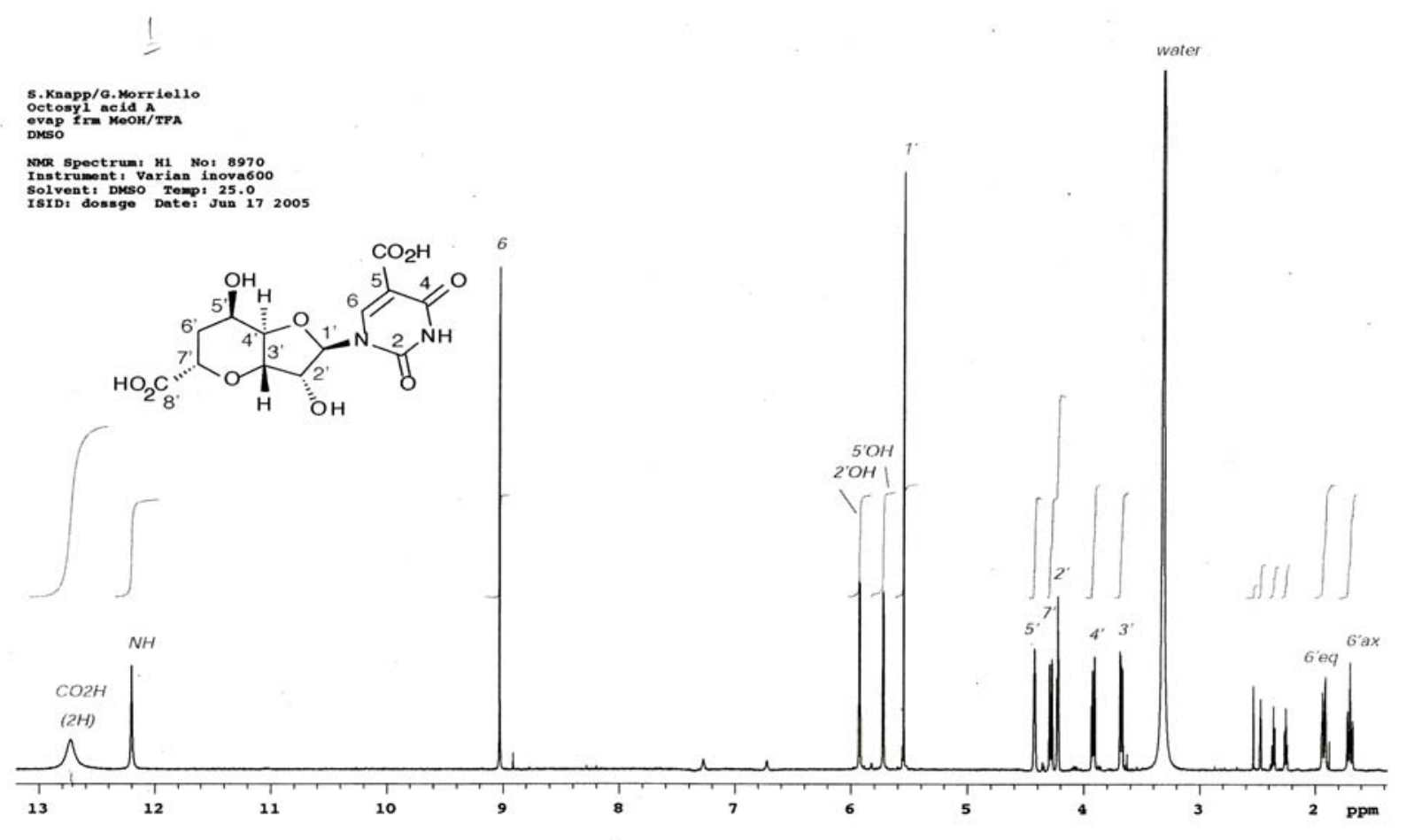

${ }^{1} \mathrm{H}$ NMR of compound $\mathbf{1}$ (DMSO- $\mathrm{d}_{6}$ ) 